\title{
Nucleotide sequence of the lantibiotic Pep5 biosynthetic gene cluster and functional analysis of PepP and PepC Evidence for a role of $\mathrm{PepC}$ in thioether formation
}

\author{
Claudia MEYER', Gabriele BIERBAUM', Christoph HEIDRICH', Michaela REIS', Iörg SÜLING', Maria I. IGLESIAS-WIND' \\ Christoph KEMPTER ${ }^{2}$, Ernst MOLITOR' and Hans-Georg SAHL'
}

Institut für Medizinische Mikrobiologie und Immunologie, Universität Bonn, Germany

Institut für Organische Chemie, Universität Tübingen, Germany

(Received 24 April/19 June 1995) - EJB 95 0646/2

The biosynthesis of Pep5, a lanthionine-containing antimicrobial peptide, is directed by the 20-kbp plasmid pED503. We identified a 7.9-kbp DNA-fragment within this plasmid which covers the information for Pep5 synthesis in the homologous host Staphylococcus epidermidis 5 which has been cured of pED503. This fragment contained, in addition to the previously described structural gene pepA and the immunity gene pepI [Reis, M., Eschbach-Bludau, M., Iglesias-Wind, M. I., Kupke, T. \& Sahl, H.-G. (1994) Appl. Env. Microbiol. 60, 2876-2883], a gene pepT coding for a translocator of the ABC transporter family, a gene pepP coding for a serine protease and two genes $p e p B$ and $p e p C$ coding for putative modification enzymes; the gene arrangement is pepTIAPBC. We analyzed the biosynthetic genes with respect to their function in Pep5 biosynthesis. Deletion of PepT reduced Pep5 production to about $10 \%$, indicating that it can be partially replaced by other host-encoded translocators. Inactivation of PepP by site-directed mutagenesis of the active-site His residue resulted in production of incorrectly processed Pep5 fragments with strongly reduced antimicrobial activity. Deletion of $p e p B$ and $p e p C$ leads to accumulation of Pep5 prepeptide in the cells without excretion of processed peptide. A pepC-deletion clone did not excrete correctly matured Pep5 but it did produce fragments from which serine and threonine were absent. Only one of these fragments contained a single lanthionine residue out of three expected while the remaining, unmodified cysteine residues could be detected by reaction with Ellman's reagent. These results demonstrate that $\mathrm{PepC}$ is a thioether-forming protein and strongly suggest that $\mathrm{PepB}$ is responsible for dehydration of serine and threonine.

Keywords: lantibiotics; Pep5 biosynthetic gene cluster; PepC, thioether-forming enzyme; PepP, serine protease.

Pep5 is a tricyclic peptide produced by Staphylococcus epidermidis 5 (Sahl and Brandis, 1981) which belongs to the family of lantibiotics, a designation introduced to characterize lanthionine containing peptides with antimicrobial activity (Schnell et al., 1988). In contrast to conventional peptide antibiotics, which are synthesized by multienzyme complexes, lantibiotics derive from gene-encoded precursor peptides. These precursors consist of a leader sequence and a propeptide part which is posttranslationally modified to give the mature lantibiotic. It was proposed that in a first modification step the serine and threonine residues of the propeptide part are dehydrated to didehydroalanine (Dha) and didehydrobutyrine (Dhb) (Schnell et al., 1988). Such dehydrated prepeptides have been isolated from S. epidermidis 5 (Weil et al., 1990). In a second step thiol groups of cysteine

Correspondence to H.-G. Sahl, Institut für Medizinische Mikrobiologie und Immunologie der Universität Bonn, Sigmund-Freud-Strasse 25, D-53105 Bonn, Germany

Fax: +492282876763 .

Phone: +49228 2875704

Abbreviations. Lan, lanthionine; MeLan, 3-methyllanthionine; Dha, didehydroalanine; Dhb, didehydrobutyrine.

Note. The novel nucleotide sequence data published here have been deposited with the EMBL sequence data bank and are available under accession number Z49865. The novel amino acid sequence data have also been deposited with the EMBL sequence data bank. residues react with the double bonds of some of the Dha and Dhb residues to form lanthionine or methyllanthionine, respectively. Some lantibiotics contain further modified residues such as D-Ala (Skaugen et al., 1994) or the C-terminal S-aminovinylcysteine (Kupke et al., 1994). For nisin it has been demonstrated that, after modification of the propeptide part, the prelantibiotic is exported from the cell, followed by removal of the leader sequence (Van der Meer et al., 1993).

Obviously, such a maturation pathway requires a dedicated biosynthetic machinery composed of several proteins. The genes for these proteins have been found to be arranged in gene clusters as described for nisin (Engelke et al., 1992, 1994; Kuipers et al., 1993; Van der Meer et al., 1993), subtilin (Klein et al., 1992, 1993; Klein and Entian, 1994; Chung et al., 1992; Chung and Hansen, 1992) and epidermin (Schnell et al., 1992). Typically, these clusters include genes for specialized peptidases belonging to the subtilisin family of serine proteases for proteolytic processing, an export protein of the $\mathrm{ABC}$ transporter family, proteins involved in immunity, and two component regulatory proteins. In addition, in all of these clusters two genes designated $l a n B$ and $\operatorname{lan} C$ were found, the corresponding proteins of which do not have any similarity to known sequences. As dehydration of peptide hydroxyamino acids and thioether formation are hitherto undescribed reactions, novel catalysts were expected to be 
found, thus making these LanB and LanC proteins likely candidates. However, no experimental evidence concerning the role of these two proteins has been reported so far.

Lantibiotic gene clusters may be located on the chromosome as in the case of subtilin (Banerjee and Hansen, 1988), on plasmids as in the case of epidermin (Schnell et al., 1988), or on a transposon as shown for nisin (Dodd et al., 1990). The structural gene for Pep5 biosynthesis, pepA, is located on the 20-kbp plasmid pED503 in the producer strain $S$. epidermidis 5 (Kaletta et al., 1989). Upstream of pepA, the immunity gene pepI was found which confers protection against Pep5 to the producer strain, while downstream an open reading frame starts which codes for the N-terminal fragment of a putative protease (Reis et al., 1994). A 6.8-kbp fragment of pED503 that comprises pepI, pepA and a further $5.3-\mathrm{kbp}$ of downstream sequence is sufficient for Pep5 biosynthesis in a variant of $S$. epidermidis 5 that has been cured of pED503, although the production rate of this clone is lower than that of the wild-type strain (Bierbaum et al., 1994). Here we report the nucleotide sequence of the $6.8-\mathrm{kbp}$ fragment and of an additional $1.072-\mathrm{kbp}$ upstream of pepI. We identified and functionally analyzed the processing protease PepP and the transporter PepT. In addition, we found the genes for the putative modification enzymes PepB and PepC and present, for the first time, experimental evidence for their role in lanthionine biosynthesis.

\section{MATERIALS AND METHODS}

Bacterial strains and plasmids. The bacterial strains listed in Table 1 were kept as glycerol stock cultures at $-70^{\circ} \mathrm{C}$ or subcultured weekly on blood agar. Both Escherichia coli strains were used as hosts for recombinant DNA, E. coli BMH 71-18 mut $\mathrm{S}$ and the vector $\mathrm{pALTER}$ were used for site-directed mutagenesis. The plasmids pBR322, pEMBL $18^{+} / \mathrm{pEMBL} 9^{+}$and pUC19 were used for transformation of $E$. coli; pCU1 is an $E$. coli/Staphylococcus shuttle vector, which was kindly provided by R. Rosenstein and F. Götz (Tübingen; Augustin et al., 1992).

DNA cloning, sequencing and amplification by the polymerase chain reaction (PCR). Plasmid DNA of $S$. epidermidis 5 was purified as described previously (Reis et al., 1994). Plasmid DNA of $E$. coli strains was isolated by the methods of Holmes and Quigley (1981) or Bimboim and Doly (1979); DNA for sequencing was purified on Qiagen 20 columns (Diagen, Hilden, FRG). Restriction enzymes and T4 DNA ligase were supplied by Boehringer (Mannheim). E. coli strains and S. epidermidis $5 \mathrm{Pep5}^{-}$were transformed by electroporation (Augustin and Götz, 1990).

For determination of the sequence downstream of pepP, the $6.8-\mathrm{kbp}$ insert of pGB7 was digested with the restriction enzymes HindlII and EcoRI. The fragments obtained were cloned in pUC19 or pEMBL19+ and designated pCM4/1-4/5 (Table 1). In order to sequence the DNA upstream of pepI, deletion clones of pCM1 (designated pJS9 to pJS12, Table 1) were constructed using the double-stranded nested deletion kit from Pharmacia. The instructions of the manufacturer were modified as follows: the restriction enzymes EcoRI and AatII were used to linearize the plasmid; deletion reactions were performed without $\mathrm{NaCl}$ at $30^{\circ} \mathrm{C}$; samples were taken at $1-\mathrm{min}$ intervals; after the $\mathrm{S} 1$ nuclease digest, Klenow polymerase was used to obtain a sufficient number of blunt ends; ligation was performed in the presence of $0.25 \%$ Nonidet P40. The clones were hybridized with a PCR fragment covering pepA which was labelled with $\left[{ }^{32} \mathrm{P}\right] \mathrm{dATP}$ using the random primed DNA labelling kit from Boehringer (Mannheim). Southern hybridization was performed according to established protocols (Sambrook et al., 1989). Clones lacking progressively about 300 bp were selected.
Double-stranded plasmid DNA was sequenced by using the dideoxynucleotide chain-termination method (Sanger et al., 1977), the $T 7$ sequencing kit (Pharmacia) and $\left.{ }^{35} \mathrm{~S}\right] \mathrm{dATP}[\alpha \mathrm{S}]$ (Amersham). Oligonucleotides used for sequencing and amplification were synthesized with a 391 PCR Mate (Applied Biosystems). Sequence data were analyzed with ClustalW (kindly provided by D. Higgins; Higgins et al., 1992; Thompson et al., 1994), readseq (kindly donated by D. Gilbert), the GENIUS HUSAR program suite at the DKFZ (Heidelberg) and the Genetic Data Environment program suite (kindly provided by S. Smith).

RNA isolation and Northern hybridization. RNA was prepared by the minilysate method of Holmes and Quigley (1981) as modified by Oskouian and Stewart (1990) for isolation of RNA from staphylococci. S. epidermidis 5 cells were grown in tryptic soya broth medium (Oxoid, Basingstoke, England: $17 \mathrm{~g} / \mathrm{l}$ Bacto tryptone, $3 \mathrm{~g} / \mathrm{l}$ Bacto soytone, $2.5 \mathrm{~g} / 1$ Bacto dextrose, $5 \mathrm{~g} / \mathrm{l}$ $\mathrm{NaCl}, 2.5 \mathrm{~g} / \mathrm{l} \mathrm{Na} \mathrm{NPO}_{4}$ ) containing $0.7 \%$ (mass/vol.) glycine to an absorbance of 1.0 at $578 \mathrm{~nm}$, pelleted, suspended in $50 \%$ sucrose, $20 \%$ Triton, $0.5 \mathrm{M}$ EDTA, $1 \mathrm{M}$ Tris, pH 6.8 and incubated with lysostaphin $(0.71 \mathrm{mg} / \mathrm{ml})$ for $40 \mathrm{~s}$ at $100^{\circ} \mathrm{C}$. After addition of $20 \mathrm{U}$ RNasin (Promega Corporation, Heidelberg), the cold sample was centrifuged and the RNA was precipitated from the supernatant with ethanol/3 $\mathrm{M}$ sodium acetate $\mathrm{pH} 4.8$. After digestion with DNase I (Boehringer, Mannheim) according to Ambulos et al. (1987) and denaturation with glyoxal/dimethylsulfoxide (McMaster and Carmichael, 1977), total RNA was separated on a $1.75 \%$ agarose gel (Seaplaque, FMC Corporation, Rockland, USA) using $10 \mathrm{mM}$ sodium phosphate, $\mathrm{pH} 7$. Vacuum blotting was performed with a Vacu Gene XL (Pharmacia) within $90 \mathrm{~min}$ and a suction of $50 \mathrm{~cm} \mathrm{H}_{2} \mathrm{O}$. Complete RNA transfer was controlled by staining with ethidium bromide. After a short incubation in $1 \mathrm{mM}$ EDTA, $10 \mathrm{mM}$ Tris $\mathrm{pH} 8$ at $96^{\circ} \mathrm{C}$, the filter was dried for $2 \mathrm{~h}$ at $80^{\circ} \mathrm{C}$.

As hybridization probes [ $\left.{ }^{32} \mathrm{P}\right] \mathrm{dATP}$ randomly primed PCR fragments of pepI and pepA were used. These were synthesized according to Saiki et al. (1988) using pMR4 as a template; the primers were: pepl-5' [5'(ATGAACATATACTTAAAAGTAAT) $\left.3^{\prime}\right]$, pepI-3' [5'(TAAAGTTTATCTTTTTTGTTGC) $\left.3^{\prime}\right]$; pepA- $5^{\prime}$ [5'(TATTTATAGAGGAGGTGGTTA) $3^{\prime}$ ], pepA-3' [5'(GAGTGGTTTCCCATACTATT) 3']. Hybridization was performed using the formamide protocol and Zeta-probe membranes (BioRad).

For transcription start site analysis, primer extension studies were performed using the following oligonucleotides: $p e p A-5^{\prime}$ with the sequence $5^{\prime}$-GGTTCAAGTTCATCAGTG- $3^{\prime}$ and pep $I$ $5^{\prime}$ with the sequence 5'-CCATTGCTTAGTCGTTA-3'; both were labelled with the 5'-labelling kit from Boehringer (Mannheim; Maxam and Gilbert, 1980). The primer extension was performed with reverse transcriptase (Boehringer, Mannheim) as described by Poolman et al. (1990). The half-life of the pepl and pepA mRNA was measured by the rifampicin $(0.1 \mathrm{mg} / \mathrm{ml})$ procedure of Ambulos et al. (1987).

Site-directed mutagenesis. Site-directed mutagenesis of PepP was performed with a commercial phagemid system as previously described for Pep5 mutant peptides (Bierbaum et al., 1994). The following mutagenic oligonucleotide was used to exchange the active-site His for Pro (the mismatch is underlined): 5'(GATTACACTGGGCCTGGAACTCAAATAATA) 3'.

Purification of Pep5 peptides and Western blot analysis of pre-Pep5. For purification of Pep5 peptides 21 tryptic soya broth was directly inoculated with the respective $S$. epidermidis clone and incubated to an absorbance of 3-4 at $600 \mathrm{~nm}$. Cells were removed by centrifugation and the supernatant directly used for purification which included adsorption chromatography on XAD2 adsorbent (Serva), cation-exchange chromatography and HPLC reverse-phase chromatography as described pre- 
Table 1. Bacterial strains and plasmids used in this study.

\begin{tabular}{|c|c|c|}
\hline Bacterial strains and plasmids & Characteristics & References \\
\hline S. epidermidis 5 & $\begin{array}{l}\text { wild-type strain; contains five plasmids (pED503-505); pED503 } \\
(20 \mathrm{kbp}) \text { confers Pep }{ }^{+} I \mathrm{~mm}^{\prime} \text { phenotype }\end{array}$ & Sahl and Brandis, 1981 \\
\hline S. epidermidis 5 Pep5 ${ }^{-}$ & cured variant of $S$. epidermidis 5, lacking pED503; Pep- Imm phenotype & Ersfeld-Dreßsen et al., 1984 \\
\hline S. carnosus TM 300 & cloning host and indicator strain & Schleifer and Fischer, 1982 \\
\hline S. simulans 22 & indicator strain & Sahl and Brandis, 1981 \\
\hline Micrococcus luteus ATCC 4698 & indicator strain & Sahl and Brandis, 1981 \\
\hline E. coli $71-18$ & $\mathrm{~F}^{-} \operatorname{lacL}^{4}(\mathrm{lacZ}) \mathrm{M} 15$ pro $\mathrm{AB}($ lac-proAB) thi supE & Sambrook et al., 1989 \\
\hline E. coll $\mathrm{BMH} 71-18$ mut $\mathrm{S}$ & variant strain of $E$. coli $71-18$, defective in DNA mismatch repair & Zell and Fritz, 1987 \\
\hline E. coli JM 83 & thi ara (lac-proAB) strA (lacZ) M15 & Vieira and Messing, 1982 \\
\hline E. coli JM 109 & $\operatorname{supE}^{+}$(lac-proAB) hsdR17 dam[F'traD36 pro $\mathrm{AB}^{+}$lacI'I(lacZ) M15] & Yanisch-Perron et al., 1985 \\
\hline pBR322 & $\mathrm{Amp}^{\mathrm{R}} \mathrm{Tet}^{\mathrm{R}} 4.36-\mathrm{kbp}$ low-copy vector & Bolivar et al., 1977 \\
\hline pEMBL $18+/ 19+$ & $A m p^{R} l a c Z, 3.96-k b p$ vector & Dente et al., 1983 \\
\hline pUC19 & Amp ${ }^{R}$ lacZ, 2.68-kbp high-copy vector & Vieira and Messing, 1982 \\
\hline pCU1 & $\mathrm{Amp}^{\mathrm{R}} \mathrm{Cm}^{\mathrm{K}}, 4.95-\mathrm{kbp}$ shuttle vector & Augustin et al., 1992 \\
\hline pALTER & Amp $^{\mathrm{R}} \mathrm{Tet}^{\mathrm{R}}, 5.68$-kbp phagemid & Dotto et al., 1981 \\
\hline pMR4 & 2.0-kbp BglII fragment of pED503 cloned into pCU1 & this study \\
\hline pMR7 & 540-bp PCR fragment cloned into pCU1 & Reis and Sahl, 1991 \\
\hline pSZ1 & 8.3-kbp BamHI fragment of pED503 cloned into pEMBL18+ & Bierbaum et al., 1994 \\
\hline pGB7 & 6.8-kbp SphI-BamHI fragment of $\mathrm{pSZ} 1$ in $\mathrm{pCU} 1$ & Bierbaum et al., 1994 \\
\hline pGB9 & 4.8-kbp KpnI-BamHI fragment of pSZI subcloned into pCU1 & Bierbaum et al., 1994 \\
\hline pGB10R & 6.2-kbp KpnI-BamHI fragment of pED503 in pCU1 & Bierbaum et al., 1994 \\
\hline pGRO1 & pGB10R with the mutation H53P in PepP & this study \\
\hline pCM1 & 5.0-kbp HindIII fragment of pED503 in pBR322 & this study \\
\hline $\mathrm{pCM} 4 / 1$ & 2.0-kbp HindIII fragment of pGB7 subcloned into pUC19 & this study \\
\hline $\mathrm{pCM} 4 / 2$ & $2.2-\mathrm{kbp} E c o \mathrm{RI}$ fragment of pGB7 subcloned into pUC19 & this study \\
\hline $\mathrm{pCM} 4 / 3$ & 2.0-kbp HindIII fragment of pGB9 subcloned into pUC19 & this study \\
\hline $\mathrm{pCM} 4 / 4$ & 1.6-kbp EcoRI fragment of pGB7 subcloned into pUC19 & this study \\
\hline $\mathrm{pCM} 4 / 5$ & 0.9-kbp HindIII fragments of pGB7 subcloned into pEMBL19+ & this study \\
\hline pJS9-pJS12 & deletion clones of pCM1 & this study \\
\hline $\mathrm{pCM} 7$ & $\begin{array}{l}\text { 3.8-kbp kpnI-SpeI fragment derived from pGB9 and } 1.39-\mathrm{kbp} \\
\text { BglII-KpnI fragment derived from pMR4 subcloned into pCU1 }\end{array}$ & this study \\
\hline
\end{tabular}

viously (Sahl and Brandis, 1981; Sahl et al., 1985). Amino acids of peptide hydrolysates were analyzed after derivatization with $o$-phthaldialdehyde (Sahl et al., 1985).

The purified peptides were characterized by electro-spray mass spectrometry and by Edman degradation as previously described (Weil et al., 1990). For determination of free thiol groups, peptides were treated with Ellman's reagent, 5,5'-dithiobis-(2-nitrobenzoic acid). The reagent was dissolved in ethanol $(1 \mathrm{mg} / \mathrm{ml})$ and mixed with an equal volume of buffer $(0.4 \mathrm{M}$ ammonium acetate $\mathrm{pH} \mathrm{8.0)}$ shortly before use. Aqueous solutions of the peptides were supplemented with an equal volume of the reagent mixture and incubated for $30 \mathrm{~min}$ at room temperature before mass determination. For reduction of disulfide bonds prior to Ellman derivatization, peptides were treated with $2 \mathrm{mM}$ dithioerythritol for $30 \mathrm{~min}$ followed by addition of a threefold excess of Ellman's reagent. Reduction of disulfide bonds before HPLC was achieved by treating the peptides with $0.2 \mathrm{mM}$ dithioerythritol in $0.2 \mathrm{M}$ ethylmorpholine $\mathrm{pH} 8$.

For semiquantitative comparison of Pep5 production by different clones a rapid one-step procedure for Pep5 enrichment and subsequent SDS/PAGE has been described (Bierbaum et al., 1994); Western blots of prepeptides were performed according to Reis et al. (1994).

Nucleotide sequence accession number. The nucleotide sequences presented here have been deposited at the EMBL data bank under accession number Z49865.

\section{RESULTS}

The Pep5 biosynthetic gene cluster. Previous work has shown that Pep5 production in S. epidermidis 5 depends on the presence of plasmid pED503 (Ersfeld-Dreßen et al., 1984) and that, in a pED503-cured variant, production can be restored with a 6.8-kbp fragment of this plasmid (Bierbaum et al., 1994). We further subcloned this fragment using the restriction sites indicated (Fig. 1) and obtained its entire sequence (Fig. 2). Downstream of the immunity gene pepl and the Pep5 structural gene pepA (Reis et al., 1994) we identified three further open reading frames which, on the basis of sequence similarity to proteins in other lantibiotic gene clusters, were designated pepP, pep $B$ and pep $C$. Moreover, we detected the start of a fourth open reading frame on the opposite strand upstream of pepI, of which the full sequence could not be determined due to the length of the fragment. This gene was completed by sequencing deletion clones pIS9 to pJS12 derived from pCM1 (Fig. 1), and the corresponding protein was found to have sequence similarity to lantibiotic translocators of the ABC transporter family. Thus, the Pep5 biosynthetic gene cluster covers approximately $7.9 \mathrm{kbp}$ and comprises pepTIAPBC (Fig. 1, 2).

Transcriptional aspects. Closer inspection of the DNA sequence suggested the presence of two inverted repeats with features of rho-independent transcriptional terminators. The first 
A
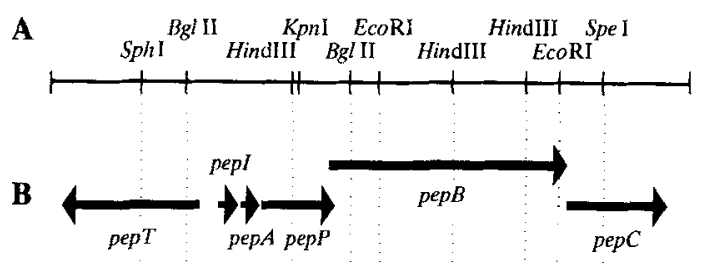

C

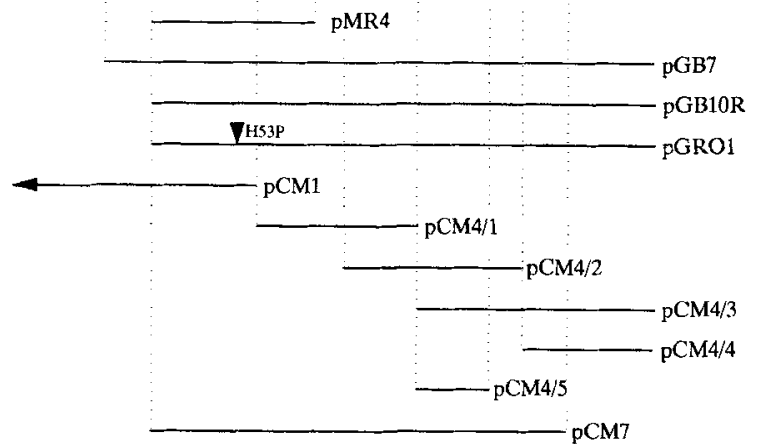

Fig. 1. Organization of the Pep5 biosynthetic gene cluster. (A) Restriction map of the 7.9-kbp segment of the plasmid pED503 covering the DNA sequence information for Pep5 production. (B) Organization of the Pep5 biosynthetic genes. (C) Subcloned fragments of the gene cluster; dotted lines indicate the restriction sites used for cloning.

putative terminator with a calculated free energy of $-56.9 \mathrm{~kJ} /$ mol is located in the short non-coding segment between pepA and pep $P$ and may allow partial readthrough (Reis et al., 1994), while the second inverted repeat follows $110 \mathrm{bp}$ downstream of $p e p C$ and is probably strong enough $(-78.7 \mathrm{~kJ} / \mathrm{mol})$ for transcription termination (Fig. 2). Potential promoters with reasonable similarity to published consensus sequences were only detected in front of pepl and pepA. Northern blot analysis with probes for both genes did not detect any transcripts longer than expected for monocistronic mRNA (Fig. 3). The pepI transcript was approximately 300 bases long, had a half-life of $1.5 \mathrm{~min}$ (Fig. 3) and started 42 bases in front of the respective ATG codon (Fig. 2). The pepA mRNA was of similar size (Fig. 3), but more stable (half-life of 7-10 min) and started 52 bases in front of the pepA start codon. On the basis of these start sites, promoter sequences are proposed as indicated (Fig. 2). The -35 region of the potential pepI promoter (TTGACA) is identical to the $E$. coli consensus sequence and the -10 region for the pepA promoter (TATAAA) has reasonable similarity to lactococcal -10 sequences (e.g. Chassy and Murphy, 1993).

The protease PepP is necessary for correct processing of Pep5. Adjacent to pepA, separated by 61 base pairs, follows pepP coding for a 285 -amino-acid gene product with a calculated mass of $32.4 \mathrm{kDa}$ (Fig. 2). PepP shows sequence similarities to subtilisin-like serine proteases, especially the conserved regions containing the amino acids of the active-site Asp20, His53, Ser228 and Asn145 of the oxyanion hole (Fig. 4). PepP is an overall hydrophilic protein without any clusters of hydrophobic amino acids. A prepro-sequence which is common with most other serine proteases (Siezen et al., 1991) is also missing, suggesting that it is not exported but localized in the cytoplasm.

In order to determine whether PepP is active and necessary for Pep5 biosynthesis, the protease was inactivated by site-directed mutagenesis exchanging the active-site His53 for Pro. The resulting clone $S$. epidermidis $5 \mathrm{Pep5}^{-}$pGRO1 accumulated unprocessed prepeptide inside the cells but did not excrete any prepeptide into the culture medium (Fig. $5 \mathrm{~B}$, lanes $4,5,6$; com- pared to the wild-type strain, lane 2). Also, Pep5 could not be found in the supernatant (Fig. $5 \mathrm{~A}$, lane 5), yet some antibacterial activity was detectable after partial enrichment. Using the Pep5 purification protocol (Sahl et al., 1985), a number of peaks were found to elute from the HPLC C18 column at a lower concentration of acetonitrile as compared to Pep5. These peaks contained mixtures of peptides with molecular masses lower than $3488 \mathrm{Da}$ which were identified as fragments of Pep5 by N-terminal sequencing and mass spectroscopy. The major components were Pep5 17-34 (with a mass of $1899.24 \mathrm{Da}$ and a N-terminal sequence of Leu-Lys-Ala), Pep5 6-34 (3106.15 Da, Ile-Arg-Ala) and Pep5 15-34 (2110.5 Da, Lys-block). Moreover, S. epidermidis 5 Pep5 $5^{-}$pGB10R (pepIAPBC) produces, in addition to correctly dehydrated Pep5, significant amounts of a Pep5 peptide with a surplus water molecule that corresponds to the presence of a Ser residue in amino acid hydrolysates (Bierbaum et al., 1994); corresponding peptide fragments with an additional mass of $18 \mathrm{Da}$ were also detected (Pep5 17-34, 1917.5 Da; Pep5 6-34, 3124.5 Da; Pep5 15-34, 2128.5 Da). Thus, in the absence of functional PepP, the Pep5 prepeptide is processed at different sites by other host proteases present, indicating that PepP is essential for correct processing of Pep5. Additionally, only in the PepP-deficient clone can a peptide be detected by immunoblotting with anti-leader peptide antiserum which has approximately half the mass of the prepeptide (Fig. 5, lane 4). Apparently, this peptide represents the incorrectly processed leader peptide which is not subjected to rapid degradation when additional amino acids are attached to its C-terminus due to processing at an incorrect site in the propeptide part of pre-Pep5. Activity determinations of the Pep5 fragments against Staphylococcus simulans 22 gave minimal inhibitory concentrations of $0.5-3.0 \mathrm{mg}$ peptide $/ \mathrm{ml}$ as compared to $1.2 \mathrm{ng} / \mathrm{ml}$ for native Pep5, i.e. native Pep5 is six orders of magnitude more active than the fragments; this corresponds to the almost complete loss of production of antibacterial activity by the PepP-deficient clone as compared to the wild-type strain.

The modification enzymes PepB and PepC. Downstream of pepP, with an overlap of $14 \mathrm{bp}$ and shifted by +1 base pair, a large open reading frame starts which codes for a protein of 967 amino acids and of a calculated molecular mass of $116 \mathrm{kDa}$ (Fig. 2). This putative protein PepB has sequence similarity to NisB (Engelke et al., 1992), EpiB (Schnell et al., 1991) and SpaB (Gutowski-Eckel et al., 1994). Although the overall amount of identical amino acids between these LanB proteins is only in the range of $20 \%$, several segments are highly conserved (Fig. 6). Such segments are between residues 80 and 110 (RS/ TTPF/YGXXS) and the C-terminal YXXEXXRYGG motif around position 850 with two further conserved Glu residues in its close vicinity; however, any predictions as to the functional importance of these segments seem premature. Hydrophobicity plots indicate that $\mathrm{PepB}$ in accordance with other LanB proteins is rather hydrophilic and that it has only one major hydrophobic stretch in the C-terminal part.

Downstream of pepB and with a -1 base pair shift follows pep $C$ coding for a putative protein of 398 amino acids with a calculated molecular mass of $42.2 \mathrm{kDa}$ (Fig. 2). PepC has significant sequence similarity to the other LanC proteins described so far with identity values slightly higher than calculated for PepB. Amino acid sequence alignments reveal several segments with significant similarity. Most of these segments contain amino acids with inert side chains and a number of regularly positioned Gly residues which could be of structural importance. However, towards the C-terminus some conserved sequence clusters contain residues which may be functionally relevant such as the NXGXAHGXXG around position 230, the 
Pept

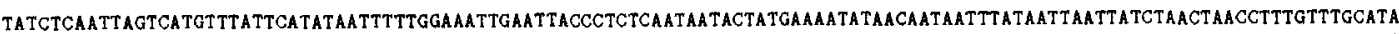

TATAAACAATACTAAAAATTAATTTATTACTACTCAagGaTATGgGCATTAARAGGGTAATAGATTTTTATATTHACTAGACGCCAAGAATTATCAGCTATTCGCTACGGTTAATATTA

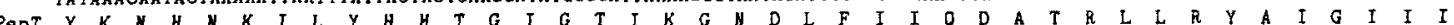
GCATCAGGATAAAACTTTATTCAATAATTCACGTAAAACTTAAAAAAAAAGTGAAAGTGATAGATTTGATCGGCAACGAAGTAGGTTGTTATTCTATAGTCCTAAAAATTAATTTAAAG

Popt T T R N Q F L H H L A H Q I K K E S E S D L S A T A F D L L L I D P N K I L N R ACGTTATAATTRGGAGACAARAACAGGGGGTCTTTCAAAATACGGCGAAGAGGTTAAACTCTCAGCATAACTACTCCATTTAATGATTATTTTAGTACTCTTAAACGGTTTTATCTTAT

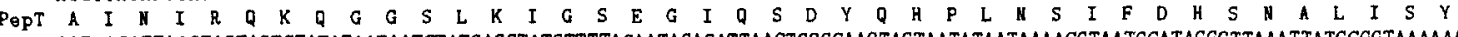
CATAAGATTAAGTAGTAGTCTATATAATAATCTATGAGGTATGTTTTACAATAGAGATTAACTGGGCAAGTAGTAATATAATAAAACGTAATGCATAGGGTTAAATTA TGCGGTAAAAA

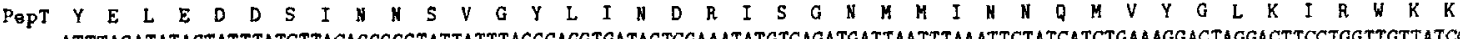
ATTTAGATATAGTATTTATCTTACAGGGGGTATTATTTAGGGAGGTGATAGTCGAAATATGTCAGATGATAATA Pept L $D$ I $Y$ I ACAAAAAAATAAATA TCCTTGTCGCTTTCTTTGTAAAAGGTCATGTAAAAATCTTAGTATTCTTTTTATATGACTTAATTTTTACTCAAGAAATAAAACCCCATATAAAAGATTTAAGTC

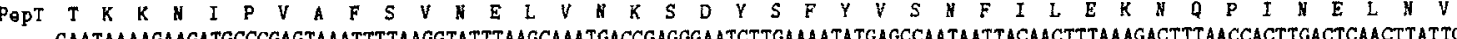
GAATAAAAGAAGATGCCCGAGTAAATTTTAAGGTATTTAAGCAAATGACCGAGGGAATCTTGAAAATATGAGCCAATAATTACAACTTTAAAGACTTTAACCACTTGACTCAACTTATTO

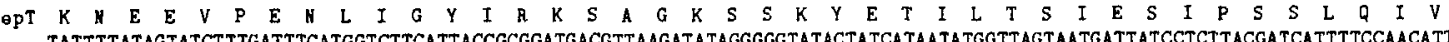
TATTTTATAGTATCTTTGATTTCATGGTCTTCATTACCGCGGA TGACGTTAAGATATAGGGGGTATACTATCA TAATATGGTTAGTAATGATTATCCTCTTACGATCATTTTCCAACA TT

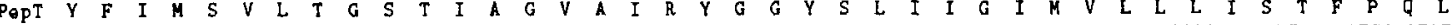
ATAACGATAATAGAATCGTACGAATTACAAATCAAATRTTTATGACCTATCAAAAAGAAAACACAATAAATTGAGTTTGAGAAGTAATCATCTTTAAAATTGATTTGCTTATCGACTATA 1200

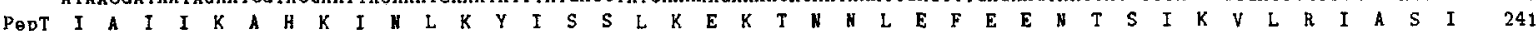
ATGTGCAGGATATCACGGACATTTTAGTCGTTGAAAAACAACTCAAAATTTTCTÁTCAAAGAGATAATATAKTGGATTACCATKTTATTGGTAATCTTTATATCCTTAATATTATTTTCA 1320

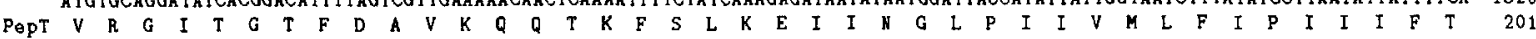
ATTATTTCAGTAAAAGGTTAGGTAATATTTTTCGTATCATTATCTTGGATATTCACAATATTTTCTTCCATATTAACGTCCATTAAAAACTCTTTATTTTAACAAATAATTCCTTCATAG 1440

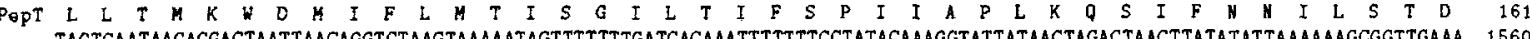
TAGTCAATAAGACGACTAATTAACAGGTCTAAGTAAAAATAGTTTTTTTGATCACAAATTTTTTTCCTATACAAAGGTATTATAACTAGACTAACTTATATATTAAAAAAGCGGTTGAAA 156O

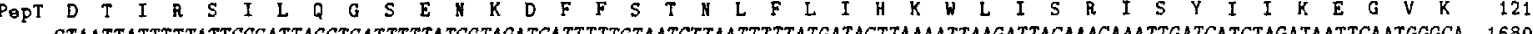
CTAATTATTTTTATTCGGATTAGGTGATTTTTA TCGTAGATCA TTTTTGTAATCTTAATTTTTATGATACTTAAAATTAAGATTACAAACAAATTGATCATCTAGATAATTCAATGGGCA 1680 ATCTTCTCCCTGATACTAAAGTCACTATGACGGCTACCTTCTTTATTAATACGTTATTATTTATTGCTGAATCCGGTAATTTAAAAACTCTTATTTTTTTTATCACCCAAAAGAAAAAA 180

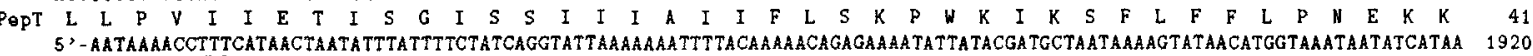
GTATTATTTIEGALGTATTGATTATAAATAAAAGATAGT-5,

Pept $M$

$p-35$

TGTTTATGTCTACTTTGAATATACTTTTT TTGACAMATTAAAGATAAACTARGCGATCTATAAGATTATCTAAAT $\downarrow$ transcription start

RBS

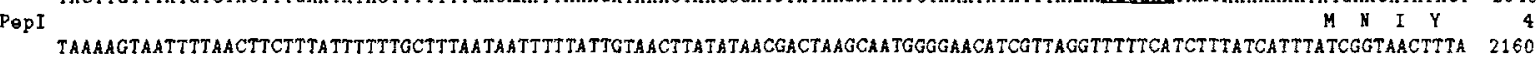

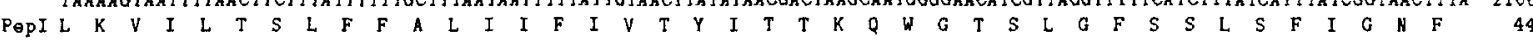
TTTACGATTRTTCAACGAAATTAAGTGATAAAAAATATGARAAAAGAATAAATAGCAACAAAAAAGATAAACTTTAGTATGTTTAAATAATTAATTATAAAAAATGTATTGTTTTTTTCT $\frac{p-35}{10}$ PePI I Y D Y S T K L S D K K Y E K R I N S N K K D K L *

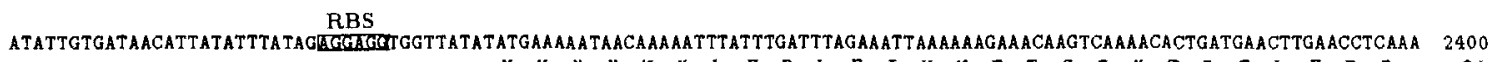
Peps CTGCTGGACCAGCGATTAGAGCT TCTGTGAAACAATGTCAGAAAACTTTGAAAGCTACGCGTTTATTT ACAGTGTCTTGCAAAGGAAAAAACGGATGTAAATAGTATGGG

PepA T TARTTAAATAATARTGAGAGTGGTTTTTTGTATGCLGGAGA

PөpP ARCATCCGGAaTTACAAGATAKTATTATTTTAAAGCAGAGCAAAAGTTTTGTGGACGATAATATCAGTGATTACACTGGGCATGGAACTCAAATARTAAGCGTRCTGACAGGAAGCAT 2760

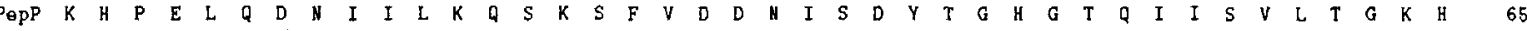
TATATATCAGGATTCCTTCCTAATATTAATATTGTATTATATAAAGTTACAAATTTTTATGGAAAAAGTAAAGCAATTGATATATATAAAGCTTTAAAAATTGGGATTAAAAATAATTTT 2880

POPP $Y$ Y $I$ I $S$ S $G$ G AAAGTTATAAATATAAGTTTCTCAGGTGAAATATACGATAAAAAATTAATGAAAAAATTTCAAAGTATTATATATGAAGCTTATAAAAAAAATATAGTAATTTGCTGGAGTTCAATGAAT 300O

PepP $K$ K V I I AATCTACAAAAATCTGCTAATCATGGAAATAABAACATGGTACCTAATCAATTAGAAAAAGTTTTCAAAATCGGCGATTTAAACTATTATAATTCGGTTGATTTTGTTGCTCCAGGTGGA 3120

PepP N L Q GAAACAATAAATGGAAATGAATTAGAGGAAATTACAACAATGATAGTTGCTAACACTAGATTAGTACAAAAAATTTCAGATCACTATATGGGACTTCCTATTGGATATACTTTAAATATG 3240

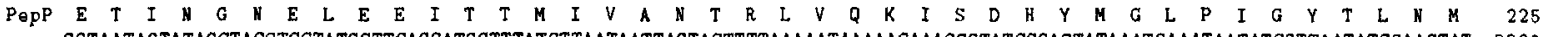
GGTAATAGTATAGCTACCTCCTATGCTTCAGGATGCTTTATGTTAATAATTAGTACTTTTAAAAATAAAAACAAACGGTATCCGAGTATAAATGAAATAATATCGTTAATATCGAAGTAT 3360

PepP G

GACGATAAAGAAGAAATTTAATTGAAATTACAABBSGGG GATTGAAGATGAAATTGTTTGATTGGTATATGGTTAGAGAACCAATTTTAAACATTAATGATTTAAAGATTATAAAAAA 3480

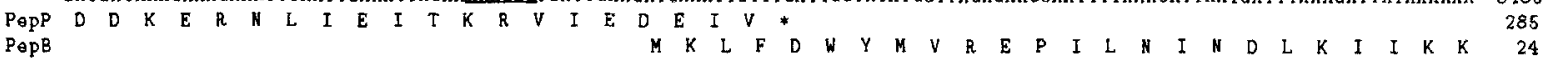
$\begin{array}{llllllllllllllllllllllllr}M & K & L & F & D & W & Y & M & V & R & E & P & I & L & N & I & N & D & L & K & I & I & K & K & 24 \\ \end{array}$

PepB N N L N D D D E Y AaATA TAAATTTA TCTAAAAAGAAGARAAAAAATTTATCATTAAGTTTATACAATTATATTACACGTATGATTTTAAGATCTACACCATTTGGGTTTATGTCATCTATAAATATAAAAGC 3720

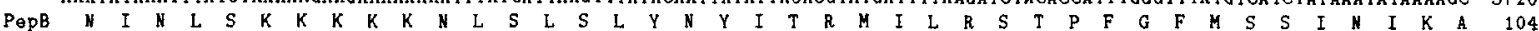

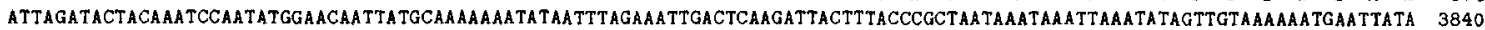

P TCTAAAAAAAAATTCTAA TGTTTACGAAGATACAACTCATTTTTATATCCCATATCAAATGCAATT AGAAGGAACAAATACAGTACCTAATAATATTAGTGTGAAAAAGAATGACTGTC 396O

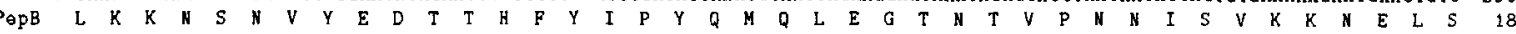

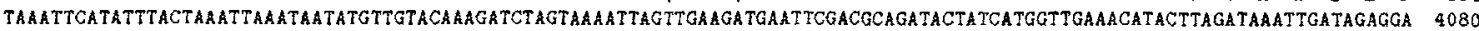

$\begin{array}{llllllllllllllllllllllllllllllllllllllllllll}\text { PepB } & K & F & I & F & T & K & L & H & \text { H } & M & \text { L } & Y & K & D & L & V & K & L & V & E & D & E & F & D & A & D & T & I & M & V & E & T & Y & L & D & K & L & I & E & E & 224\end{array}$ AAATTTATAGTTACTGAACTAGAAGATGCTATCAGTCATAAAGA TCGTGACATATTCTTGAT RAAAAAATTAGAACAAAAGGGTTTTCTAATAGTTATTATTATAAGGCTTTAAAAGA 4200

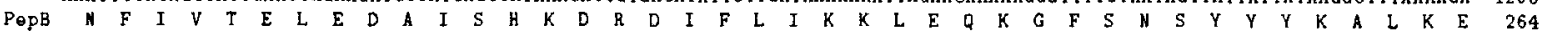
AATATACGATA TTCGTCAAATTA TGGAAAAAGGGAATATACATGACGATATACTGTATCGAATTATAGAGGTAAAAAAATTTTTAAAAGAAAAGTTTAATTTAGATGTTCACAATATTTT 4320

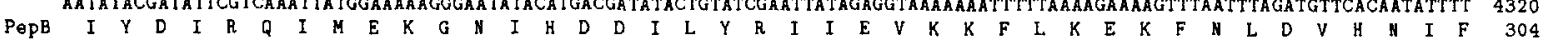
TAAAGTAGACACTATAGATACTAATATCGAAATCGATTTATCTAAATCTGAaATAAaTAACATAAAAaAaGTAaTCGaTATOCTTCTTTACTTACCAAGTGATTATGATAaTAGTTTACA 4440

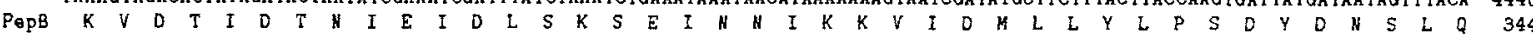
AGARTRTAAAAACAAATTTTTAGAARTATATGGTCAAGATGAATATGTTAATATTCTTAAACTTTTAAATAAAAATACAGGAATCCAATATCCTATTAATATTTATAATAATAAAGCCTT 45 SO

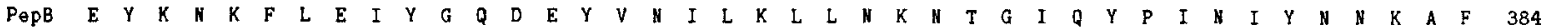
TCAATATAATAATGAAAAAGTTTATTCTCTTTTAACTGAATGGCAGTATAAAGCCATTAGAGACAAAACAGATATA ATACTTAATGAAGAAGGAATAGAACTATTGAAAAGAGTGGGGAA 4680

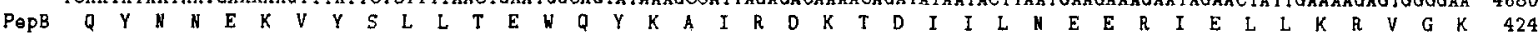
AAACCTATTGATAAATCGTTTGATATGGTTTTTACTGTTACTAAAGATGGATTTAACAATAATATTTATCATTTAAACGATAATGTTACGTCTTTAAAGGCTACTAATATATATGGGCG 48OO

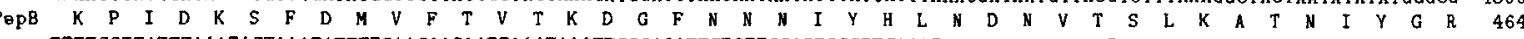
TTTTCGTTATTTAAATACTAAATATTTTGAAGAACAATTAAATAAATTCCCAGATTCTGTTGGAGTGCCTTCAGATAATTTAAACTATCATCA TCCTAATCCCATTATTGACKATGTTAA 4920

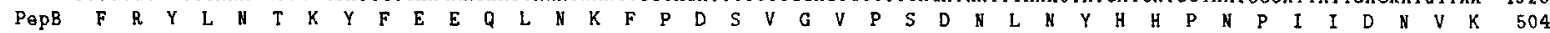

Fig. 2. Nucleotide sequence of the 7.9-kbp fragment of pED503 shown in Fig. 1 and deduced amino acid sequences of PepT (opposite orientation), PepI, PepA, PepP, PepB and PepC. Putative ribosome-binding sites (RBS) are boxed, the putative promoters (p-35, p-10) of pepI and $p e p A$ are marked above the sequence; the transcription start sites are indicated by arrows, the inverted repeats between pepA and pep $P$ and downstream of $p e p C$ are marked with lines. 


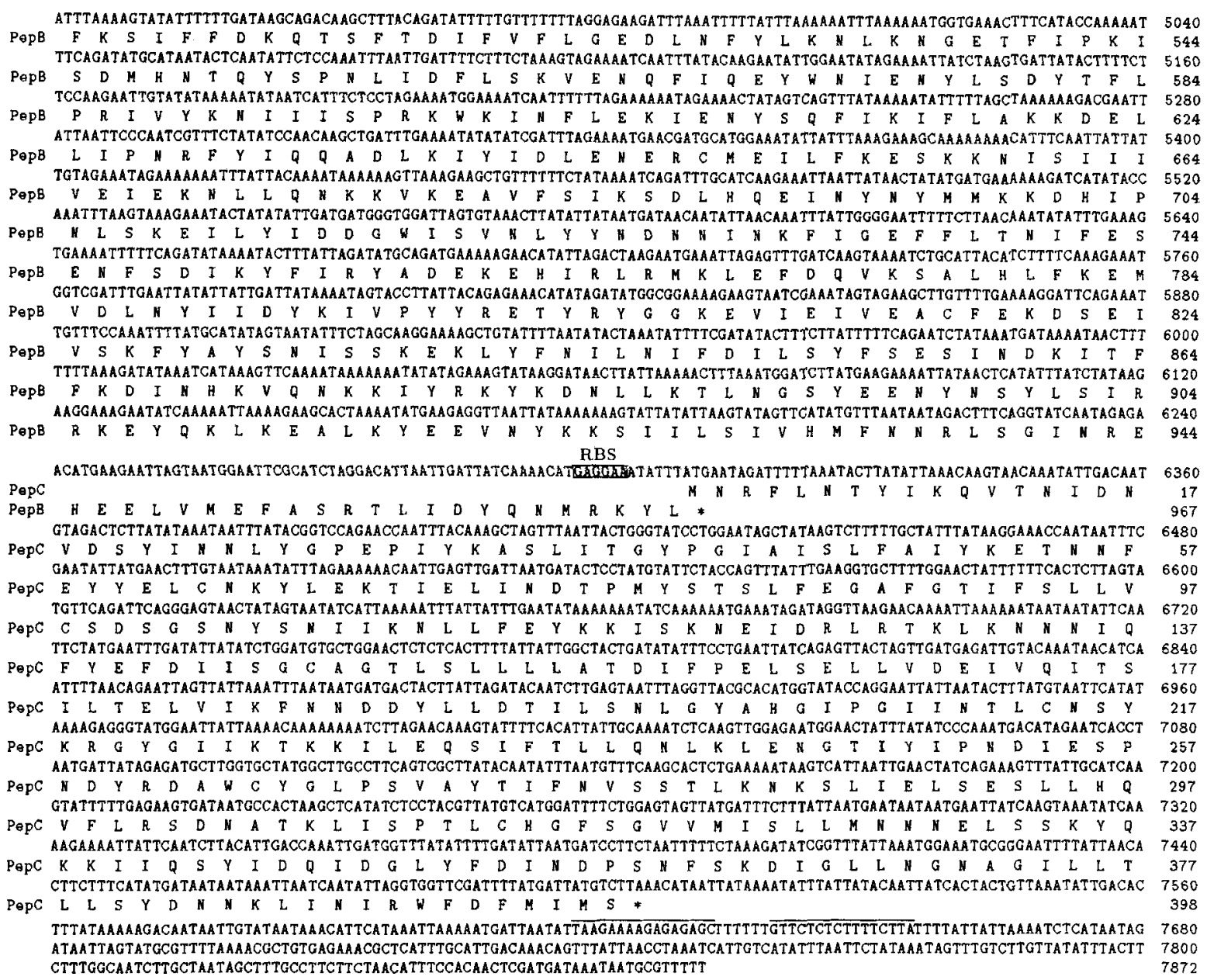

Fig. 2. (continued).

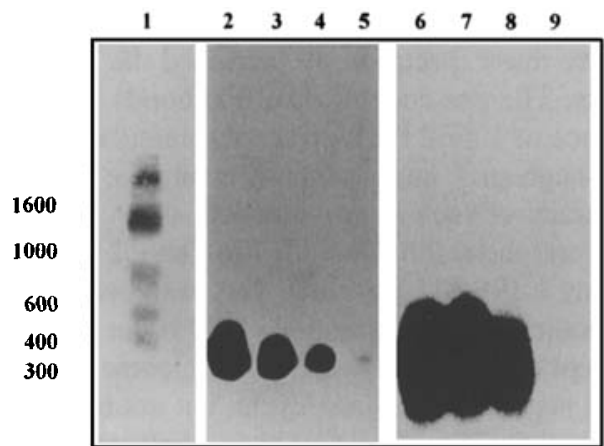

Fig. 3. Northern blot analysis of pepI and pepA transcription. Lane 1 , size standard (nucleotides); lanes 2-5, hybridization with a pepIspecific probe; RNA was prepared from cells taken after $1 \mathrm{~min}$ (lane 3), $2 \min (4)$ and $5 \min (5)$ of incubation in the presence of rifampicin; lane 2 , control without rifamipicin; lanes $6-9$, detection with a pepA-specific probe; lane 6, $0 \mathrm{~min}$; lane 7, $10 \mathrm{~min}$; lane $8,20 \mathrm{~min}$; lane 9, 40-min incubation in the presence of rifampicin.

RXXWCYG motif around position 300 and a consensus CHG some 48 residues further towards the C-terminus (Fig. 7).

Role of PepC in Pep5 biosynthesis. In order to demonstrate the necessity of $p e p C$ for Pep5 biosynthesis, the 6.8-kbp fragment of pED503 was shortened to $5.7 \mathrm{kbp}$ with SpeI (Fig. 1), thereby deleting the $231 \mathrm{C}$-terminal amino acids of pepC. The corresponding clone $S$. epidermidis $5 \mathrm{Pep}^{-} \mathrm{pCM} 7$ was not able to inhibit our standard indicator strain $S$. simulans 22 but produced a small inhibition zone when tested against $S$. carnosus TM300. This indicated that, just as with the protease-deficient clone, incompletely modified or fragmented Pep5 may be produced, although only intracellular accumulation of pre-Pep5 was visible (Fig. 5B). The culture supernatant of the PepC-deficient clone was subjected to the routine Pep5 purification protocol. Five major peaks and a number of smaller peaks and peak shoulders eluted from the HPLC reverse-phase column (Fig. 8). The five peaks were lyophilized, treated with dithioerythritol and rechromatographed; each of these five peaks split into several further peaks indicative of disulfide bond formation between different peptides during purification. After rechromatography we identified three major peptides (designated peptides 1, 3 and 5) as the dominant species in peaks I, III, and V, which also occurred in smaller amounts in peaks II and IV (Fig. 8). Peak II also contained peptide 3 , possibly linked to peptide 1 by intermolecular disulfide bonds, whereas peak IV contained peptide 5 as well as peptide 5 with a surplus water molecule. The molecular masses, amino acid composition data and $\mathrm{N}$-terminal amino acid sequences of the three major components clearly identified them as degradation products of incompletely modified Pep5 (Table 2).

Hydrolysates of these fragments did not contain Thr and Ser; only one of the Pep5 fragments which was found in peak IV contained one Ser residue; this most likely corresponds to the incompletely dehydrated Pep5 peptides observed with our Pep5 expression system (Bierbaum et al., 1994). Lan and MeLan also were not detectable except for one residue in the major peptide 


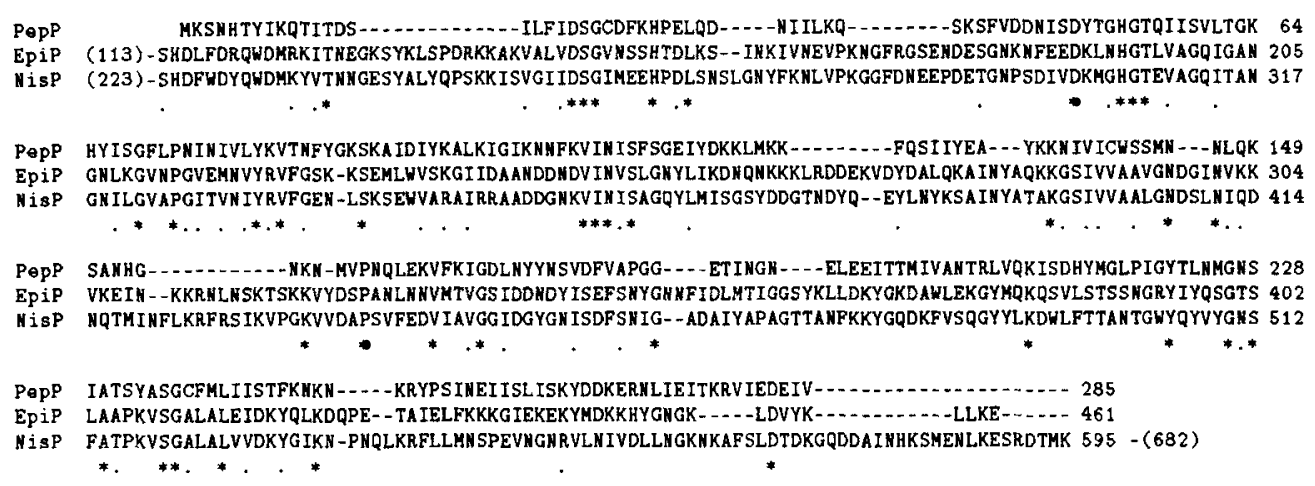

Fig. 4. Partial sequence alignment of PepP, EpiP and NisP. Sequences were compared with the Clustal W software. Identical amino acids are marked by asterisks and conservatively exchanged amino acids are marked by dots.

Table 2. Peptides produced by the pepC-deficient mutant $S$. epidermidis 5 Pep5- pCM7.

\begin{tabular}{|c|c|c|c|c|c|c|c|}
\hline \multirow[t]{2}{*}{ Peptide } & \multirow{2}{*}{$\begin{array}{l}\text { N-terminal } \\
\text { sequence }\end{array}$} & \multirow{2}{*}{$\begin{array}{l}\text { Molecular mass } \\
\text { measured (theoretical) }\end{array}$} & \multirow[t]{2}{*}{ Pep5 fragment } & \multirow{2}{*}{$\begin{array}{l}\text { Lan/MeLan } \\
\text { found }\end{array}$} & \multicolumn{3}{|c|}{ Amino acids found (present in the prepeptide) } \\
\hline & & & & & Ser & Thr & Cys \\
\hline & & $\mathrm{Da}$ & & $\mathrm{mol} / \mathrm{mol} \mathrm{pep}$ & & & \\
\hline 1 & blocked & $2766.0 \pm 0.1(2767)$ & $9-34$ & 1 & $0(2)$ & $0(3)$ & $2(3)$ \\
\hline 3 & I-R-A-blocked & $2575.5 \pm 0.5(2577)$ & $6-29$ & 0 & $0(2)$ & $0(3)$ & $2(2)$ \\
\hline 5 & blocked & $2955.6 \pm 0.6(2959)$ & $1-29$ & 0 & $0(2)$ & $0(3)$ & $2(2)$ \\
\hline
\end{tabular}

A

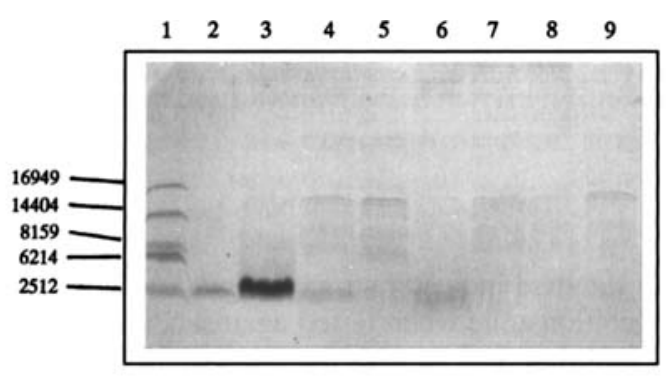

B

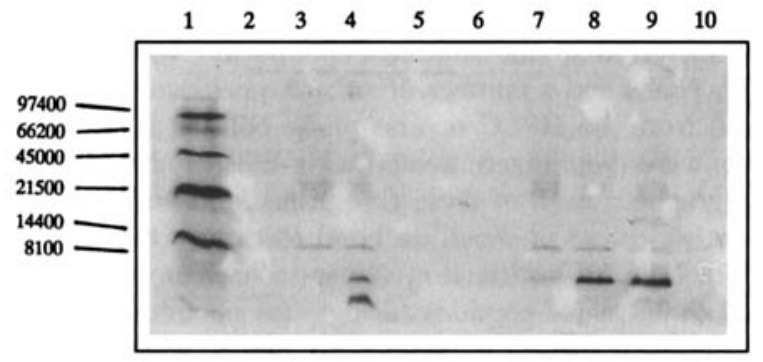

Fig. 5. (A) SDS/PAGE separation of Pep5 peptides partially purified from the supernatant of $S$. epidermidis 5 and of its indicated variants. (B) Western blot of total cell extracts of the respective strains immunoblotted with anti-Pep5 leader peptide antiserum for detection of Pep5 prepeptides. (A) Lane 1, molecular mass standard (Da); lane 2, purified Pep5, $2.5 \mu \mathrm{g}$; lane 3, wild-type $S$. epidermidis 5; lane 4, S. epidermidis 5 Pep5 ${ }^{-}$pGB10R; lane 5, S. epidermidis 5 Pep5- ${ }^{-}$pGRO1; lane $6, S$ epidermidis 5 Pep5 pCM7; lane 7, S. epidermidis 5 Pep5 pMR4; lane 8, S. epidermidis 5 Pep5 ${ }^{-}$pMR7; lane 9, S. epidermidis 5 Pep5 . (B) Lane 1, biotinylated molecular mass standard (Da); lane 2, wild-type $S$. epidermidis 5; lane $3, S$. epidermidis 5 Pep5- pGB10R; lane 4, S. epidermidis 5 Pep5 pGRO1; lanes 5, 6, S. epidermidis 5 Pep5 pGRO1 (culture supernatant); lane $7, S$. epidermidis 5 Pep5 pCM7; lane 8, S. epidermidis 5 Pep5 ${ }^{-}$pMR4; lane 9, S. epidermidis 5 Pep5 $5^{-}$pMR7; lane 10, S. epidermidis 5 Pep5 ${ }^{-}$. fragment 1 (Table 2). We analyzed the major peptides for the presence of free Cys residues using Ellman's reagent and subsequent mass spectrometry. With peptide 1 (Table 2) addition of two Ellman reagent molecules was possible (Fig. 9) indicative of two free Cys residues. Only traces of addition products of peptides 3 and 5 were detectable despite dithioerythritol treatment before chromatography, indicative of rapid intramolecular disulfide bond formation under oxidative conditions. Dithioerythritol treatment and addition of excess Ellman's reagent shortly before mass spectroscopy increased the amount of addition products. The presence of disulfide bonds is also indicated by a difference of 1.5-2 Da between the calculated and detected masses, although such interpretations must take into account the limited accuracy of such a measurement.

We interpret the results compiled in Table 2 as follows. Peptide fragment $1(9-34)$ has three Cys residues, one of which forms a thioether. Bridge formation could occur anywhere in the peptide except with Dha9, because lanthionine formation with Dha9 would just lead to a blank cycle, but not to a block during $\mathrm{N}$-terminal sequencing. Also Cys 33 is likely to be part of this thioether because peptide 1 , unlike peptides 3 and 5 , is not fragmented at position 29 ; as a result of the removal of ring $\mathrm{C}$ by site-directed mutagenesis, we found fragmentation at Gly29 to occur rather rapidly (Bierbaum et al., unpublished). The lanthionine ring in peptide 1 could impose conformational constraints on the peptide which does not allow for the remaining two Cys residues to form a disulfide bond; in contrast, this can occur rapidly with peptides 3 (fragment 6-29) and 5 (fragment 1 29) which just contain two Cys residues each.

These Pep5 fragments had no detectable antimicrobial activity as determined as inhibition zones in a lawn of $S$. carnosus TM300. Some activity eluted close to peak IV (Fig. 8) and was directly detectable without concentrating the fraction; obviously, a small amount of a peptide with a higher specific activity is also produced which, however, could not be separated and purified for further characterization. 
Pep B --MKLFDWYMVREP ILH I NDLKI IKKNNLNDDEYLNMLITF IFDKGLDVCLCHAN IELFS I IKNYQN IN- - LSKKKKKNLSLSL YNY ITRM ILRSTPFGF

EPIB GEIELDNIFVPSN IYMVRTPIFS IEL YNQFLKSDH IDYDL ILQNDIFKES IMTTTYNLYQS IGKIDWE---KDNKKTRNVKESLLKYLIRMSTRSTPYGM

Nis B -..-MIKSSFKA QPFLVRNT ILCPNDK-RSFTEYTQVIETVSKNKVFLEQLLLANPKL YDVMDKYHAG--LLKKKRVKKLFES IYKYYKRSYLRSTPFGL

SPaB -..-MKSLYTPTDYYM IRVPLVHQDLKNENSQD IDQLLHDLCNDSLFREQ ILVSSRTL YET IHTFLQAPDKLKGKKKRNFQQAILKYATRRATRTTPFGL *.

PePB MSS IN IKALDTTN PIWHNY - - AKKYHLEIDSRLLYPLINKLNIVVK - NELYLKK - NSNVYEDTTHFYIPYDMQLEGTNTVPNNISVKKNELSKF IFTKLN

EP iB LSGVALGEFSENN NIKIKDSSFHKKDVKIDG QULYKLVHYLESDYTYYKDSFVIWNDONYTYNNRLYLDWNSSITENKRNDV-LSVKYNSILVF IHENSK

N IS B FSETS IGVFSKSSQYKLMG--KTTKG IRLDTQWLIRLVHK HEVDFS-KKLSFTR-NNA NYKFGDRVFQVYT INSSELEE - - - VN IKYTNVYQI ISEFCE

SPaB FSSVG IGSFSDKH HLSFHQH -SFYKKARVDFEWL YQLIRKLENEYT -DRLSFTL-NSACYIKGDRA YLLYSTDG-KSEE--- -VSVRATSVFYL INELCG * $* * *$.

* * .

PePB - MMLYKDLVKLVEDEFDADT - IMVETYLDKLTEENFIVTELEDAISHKDRDIFLIKKLEQKGFSNSYYYKALKEI YDIRQIMEKGHIHDDILYRIIEVK EP $i B$-KNITYEELVQLISSKYS IENKEEVKVFVQELINKEI IFSDLRPTLENKNPLDYIINSLNPK - - NSLVGTLIN ISNEITKYSKMPLG - -KGEYKYLDIV H is B NDYQKYED ICETVTLCYGDEYRELSEQYLGSLIVNHYLISNLQKDLLSDFSWN TFL TKVEA IDEDKKY I IPLKKVOKFIOEYSEIE IG - EGIEKLKEIY SPAB -ESAAYQDIIRCLIDHYPHTPINKINQYVADLIDKEFL ISNLRPPMTVSDQFQYLIDQAESRH IPNEL IQACKNIQYQIDAYNRIT IG- -EGEHQYLNL I

$$
\text { *... . . . . .** }
$$

PePB KFLKEKFNLDVHN IFKVDTIDTN IEIDLSKSEIWN IKKVIDMLLYLPSDYDHSL - - QEYKHKFLEIYGQDEYVY ILKLLNKNTGIQYPIN - _... - IY EP IB NLMSOLFVSK - -NYLQ IDTY IDY SANELKOSLADN ISEAAY IL WLLSPNHFGTKT - IRNYHEFFMDKYGFEOLVNLKOLLSDINGFGYPK-... - KDSY NisB QENSQILEND-NYIQIDLIS-DSEINFDVKQKQQIEHLAEFLGNTTKSVRRTY - -LDDYKDKFIEKYGVDQEVQITELFDSTFGIGAPYHYNHPRNDFY SPAB ETMNKLIKAS - -SPLQVDAGAGDSS IQLDNETSLA ISELASMFTYMASPSANTLDHLEKYKHVFLEYGYEREVPLLEMLCSSTGIGAPATYTNPANEFF .**

$$
\text { *. *.**.*.. * * }
$$

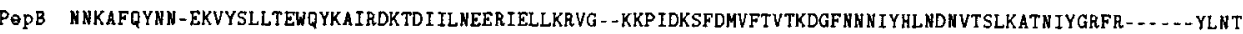
EP iB -SFSNW I AFLKEKYLLA IQUNSH IEITEHDVKNLEKNH TVSKINAPVSTE IYS - - EIYFGN SIKGYE-DF AVI SP ILGSFN AGATFGRFTGNFH IKKKND $N$ ISB ESEPSTLYYSEEEREKYLSMYVEAVKNHNV INLDDLESHYQKMDLEKKSELQG-LELFLNLAKEYEK-DIF ILGDIVGNHNLGGASGRFS---ALSPELT SPaB EETSFGEQFSPEYKQFFMRKYFESVRKKAPIQLDDE TFHRICNSE IADEEIPLSFELNFFVKLRNGR-VKLYLGPNVGSTRAGKTFGRFS - --HMSDS IS

PQPB KYFEEQLN - -KFPDSVG-VPSDNL NYHHPNPIIDNVKFKSIFFDKQTSFTD - EP $i$ B LQKEIVHHYN NYMNENG-LEI SQLNEGPLNSRNVN ILNNNR IYHTCLNLNL - - PKSD - . - IDINDIFI I GATFN -KL YL YSEKHDSR IVFVSHSMFNYEFG NiSB SYHRT IVDSVERENENKE ITSCETVFLPEN IRHANVMHTSIMRRKVLPFFT - STSHN- -EVLLTN IYIGIDEKEKFYARDISTQEVLKFY ITSMYNKTLF SPaB EIIKTLHNKEKELTECN-TKVCELSIVPHQTRSGNVTRNVSYREKEMSLFTNSALHLNDSVKAEDILIGINKDHIFYARHKTTGEILSFESNHMFNPLLM **

PePB PNL IDFLSKVEHQFIQ- - EYWNIENYLSDYTFLPRIVYKN I I ISPRKUK INFLEX IENYS - - - - QFIKIFLAKKDELLIPNRFY IQQADLKIYIDLENE Ep i SELYKFLREISFEKTKFIQP ITEEG IDS-LPFCPR I IYKN I ILKPATWKINSEMF SETEN - - - - WL NRFAT IREKWHIPKDVII AFGDN RLLLNLLND Nis B SNELRFL YEISLDDK --FGNLPWEL IYRDFDYIPRLVFDEIVISPAKWKIWGRDVNS-_.....-KMTIREL IQS-KEIPKEFY IVNGDNKVYLSQKNP SPaB THAVRLLLEISRDGKRKWNDFPWFS I YSDFK YIPEIKYKE ITLSCEQWLIYKNDLSMHSNASLEEIKSAFF EFHRT-YELPQTFY IVNADNRLLID IEND $* * \ldots$

$* * * \ldots, *$

PePB RCMEILFKESKKNISI I - - - - I IVEIEKNLLQNKKVKEAVFS IKSDLHDE INYNYMMKKDHIPN - - - LSKEILYIDDGWISVNLYYNDNH I NKF IGEFFL EPiB KHLIILKKELKKHGRIR - . - . - - - ILES--FINESHNERMLEIVTPLYKKTSLKE - - QSFIIPK - - - R RNKHFNNLKDWFS IHLSIPKTYMDNFTQDYL W is B LDMEILESAIKKSSKRKDFIELQEYFEDEN I INKGEKGRVADVVVPFIRTRALGNEGRAFTREKRVSVERREKLPFNEWLYLKLYISI NRGNEFLLSYLP SPaB CTLDVFFWELKKTNHAPLQLVAVEHDADALMDR QNDYSGEIVVPLLRKQPVKPLYLPVLNA IEGSGSDR IKMPFEDWLFIKLYCKQTREEEL IAFEIA **

PePB TNIFESEN--FSD IKYFIRYADEKEHIRLRM - KLE-- FDQVKSAL HLFKEMVDLNYI IDYKIVPYYRETYRYGGKEV IEIVEACFEKDSE IVSKFYAYEP IB PFITELKVNHF INKFFY IKFKEDEDF IKLRLLREDEDYSQ I YSF IKNWKDYCLLNSELYYYSIVDYVPEVYRYGGPHVIEDIENFFMYDSLLS IN I IQ - NiSB DIQKIVAN - -LGGNLFFLYTDPKPH IRLRI --KCSDLFLA YGS ILEILKRSRKNR INSTFDI SIYDQEVERYGGFDTLELSEA IFCADSK I IPNLLTL I SPaB DFYNQISDQ-YPVRHFFMRYRDPKPH IRLRFNGKAEVLYSLFPQLLNWLKSLREKGLVSESVITQYEREIERYGGLSLMEAAEQLFCEDSKVVEMMIRMH ...... * *** * * * **********)

PePB - - SNISSKEKL YFN ILN IFDILSYFSES INDKITFFKD INHKVQNKKIYRKYKDNLLKTLNGSYEENYNSYLS IRRKEYQKLKE- ....-ALKYEEVNYK

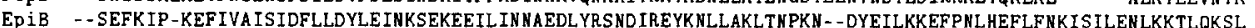
NisB KDTNNDWKVDDVS ILVNYLYLKCFFGNDNKK ILNFLN -LVSTKKVKENVHEKIEHYLKLLKVN NLGDQIFYDKNFKELKHA IKN - - - - LFLKMIAQDF $\mathrm{SPaB}$ RMKDITIS-KE IAGMVSVIQFLEQFELTFEEQLTFL.ERNSLQNEYRTEFKKDREMYIEICNSDRDWDULKTSDGGML YETLKTHKMAAAHYAFLIKKAF

\section{2} 185 188 289 290 283 285 379 381 378 383 470 477
473 479 553 570 570 578 646 658 677

PePB K-.-.--SIILSIVHMFNNRLSG INREHEELVMEFASRTLIDYQNMRKYL _.... 967

EPIB YTS--RSRIIGSF IHMRCNRIFG INPEKEKFVLSIFNEITKTKKYWDGCD-... 990

Nis B ELQ-KVYSIIDSI IHVHNNRL IGIERDKEKLIYYTLORLFVSEEYMK ......... 993

SPAB DNKDEVYSRIGSI IHLHCNRLFGTORELENKILTLCRHSLYQRYQKMNGSLAWK 1030

Fig. 6. Sequence alignment of PepB, EpiB, NisB and SpaB as described for Fig. 4.

A transporter gene, pepT, is located upstream of pepA. Another open reading frame in reverse orientation was found upstream of pepI which codes for a putative protein of 571 amino acids with a molecular mass of $64.8 \mathrm{kDa}$. Data base searches revealed similarities to the $\mathrm{LanT}$ proteins of the biosynthetic gene clusters for epidermin (EpiT'/EpiT"), subtilin (SpaT) and nisin (NisT). The highest degree of similarity with $30 \%$ identical and $24 \%$ conservatively exchanged amino acids was found between PepT and EpiT'/EpiT". PepT shows the typical features of the $\mathrm{ABC}$ transporter protein family; the $\mathrm{N}$-terminal domain covering the first 300 amino acids is predicted to contain six membrane-spanning segments while the C-terminal domain is hydrophilic and includes the ATP-binding site formed by the conserved Walker motifs A (amino acids 362-373) and B (amino acids 470-482) (Fig. 2).

Western blot and SDS/PAGE analysis of Pep5 production. Complementation of $S$. epidermidis $5 \mathrm{Pep}^{-}$with pepIAPBC resulted in a clone (pGB10R; Bierbaum et al., 1994) which produced approximately $10 \%$ of the amount of Pep5 as compared to the wild-type producer (Fig. 5 A, lane 4). After deletion of the C-terminal part of pepC from this construct the amount of peptide excreted increased (lane 6), while after inactivation of pepP hardly any peptide was detectable (lane 5). Neither the clones pMR4 and pMR7, harbouring only pepIAP and pepA, respectively, excreted any peptide in the size range of Pep5 (lanes 7,8) nor did the host control S. epidermidis 5 Pep5 ${ }^{-}$(lane 9).

Western blot analysis of SDS cell extracts from the same clones using antiserum raised against Pep5 leader peptide indicated that, in particular, clones pMR4 and pMR7 accumulated prepeptides inside the cells (Fig. $5 \mathrm{~B}$, lanes 8,9 ). Also the extract of the protease-deficient clone pGRO1 contained considerable amounts of prepeptide (lane 4) in addition to the incorrectly processed leader peptide. In contrast, no prepeptide was detectable in the wild-type producer because of rapid modification and processing (Weil et al., 1990). Only small amounts of prepeptide can be found in clones pGB10R and pCM7 (lanes 3, 7). 


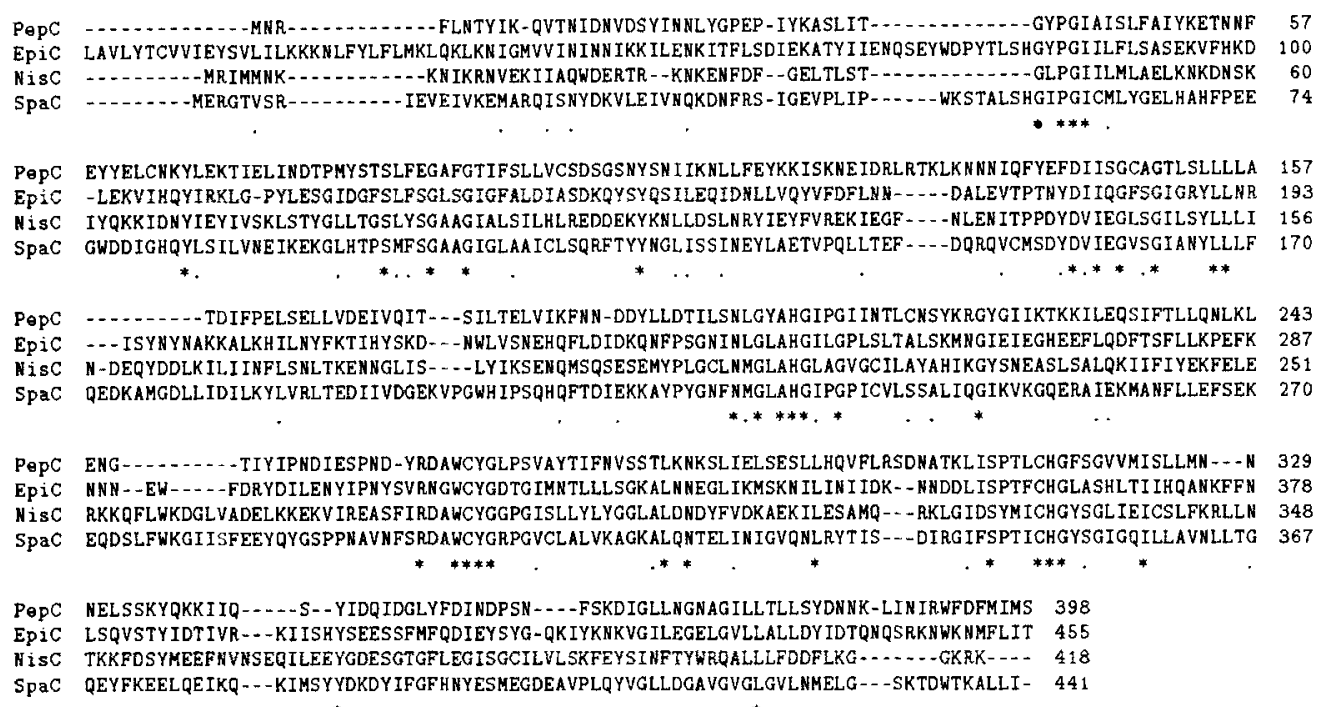

Fig. 7. Sequence alignment of PepC, EpiC, NisC and SpaC as described for Fig. 4.

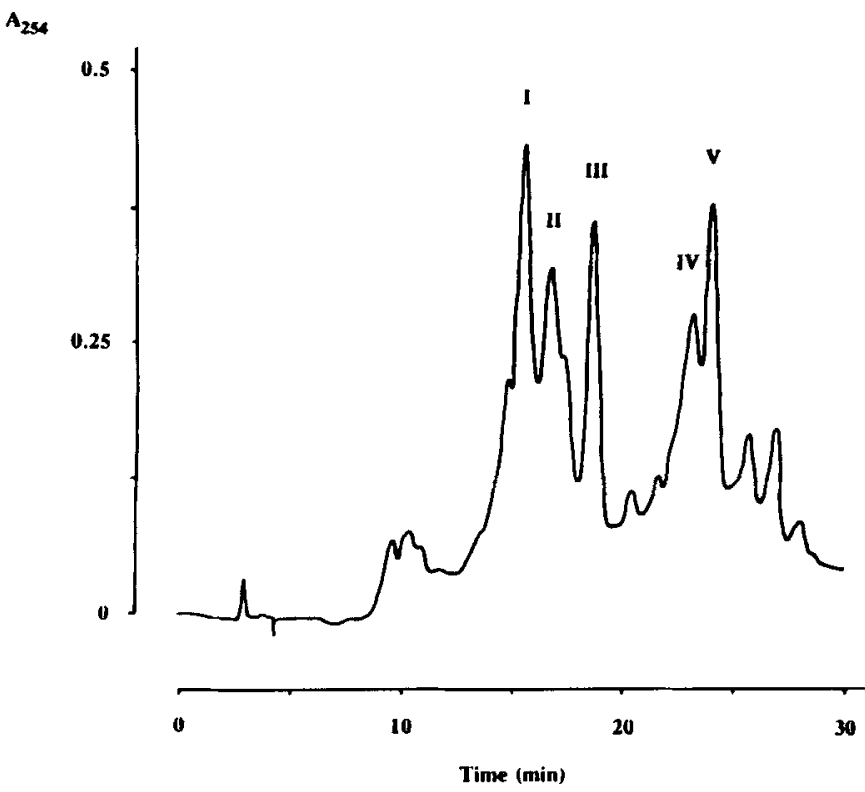

Fig. 8. HPLC elution profile of Pep5 peptides isolated from the culture supernatant of the PepC deficient mutant S. epidermidis 5 Pep5 pCM7.

\section{DISCUSSION}

The Pep5 gene cluster. Several lantibiotic biosynthetic gene clusters have been sequenced so far and a general picture is emerging on how lantibiotic biosynthesis may proceed and which classes of proteins are involved. Besides several proteins providing general functions such as processing proteases, transporters and two-component regulators, two putative modification enzymes LanB and LanC have been identified. In the case of lactocin S (Skaugen, 1994) and lactococcin DR (Rince et al., 1994) only one enzyme, such as LasM, which in the C-terminal half shares sequence similarity with the LanC proteins (Sahl et al., 1995) is sufficient for the modifications.

The Pep5 biosynthetic gene cluster comprises pepTIAPBC, i.e. besides the structural gene and the immunity gene there is information for a translocator, a protease and the modification enzymes PepB and PepC. Genes for regulatory proteins, the reg-

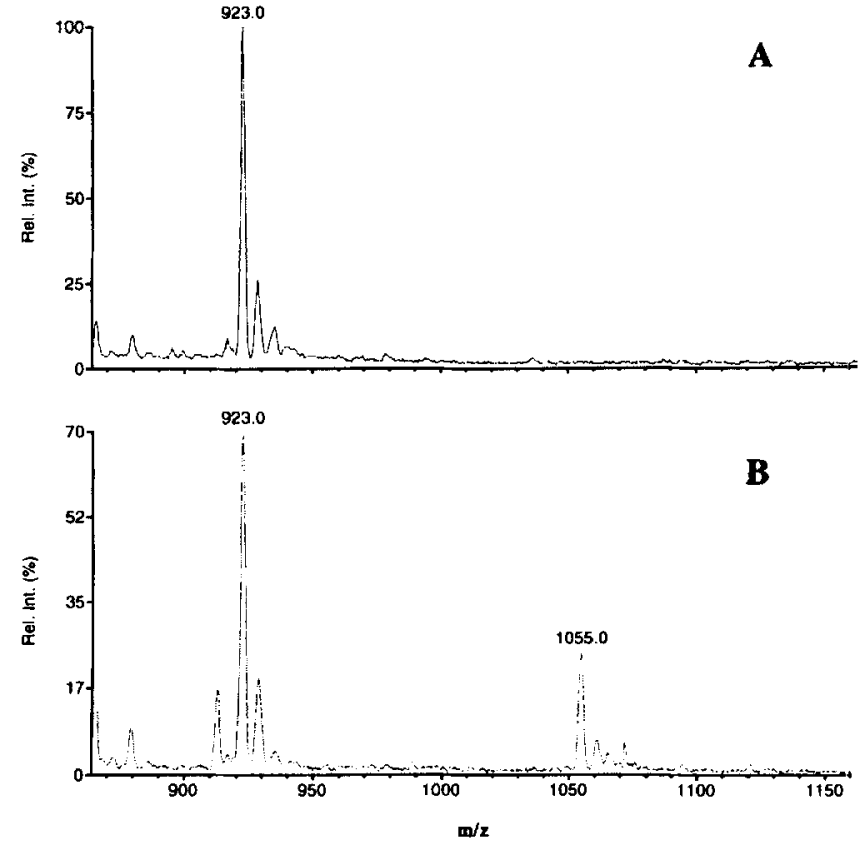

Fig. 9. Electro-spray mass spectroscopy of peptide 1 (purified from peak I of the supernatant of $S$. epidermidis 5 Pep5 $^{-}$pCM7, see Fig. 8 and Table 2) before (A) and after (B) treatment with Ellman's reagent. The figure shows the mass range of the triply charged ion $(m+3 \mathrm{H})^{3+}$ resulting in peptides of $2766 \mathrm{Da}$ and $3162 \mathrm{Da}$, respectively; the calculated mass for peptide 1 after addition of two Ellman's reagent molecules is $3162 \mathrm{Da}$.

ulator LanR and the corresponding sensor kinase LanK, are not present. Both genes were found in the nisin (nisR, nisK; Klein et al., 1993) and subtilin (spaR, spaK; Engelke et al., 1994) gene clusters, whereas in the epidermin cluster only the regulator EpiQ (equivalent to a LanR protein) is encoded (Schnell et al., 1992). The absence of pepR and pepK from the Pep5 gene cluster does not necessarily imply that Pep5 production is not regulated; rather, the failure of transforming of S. carnosus TM300 into a Pep5 producer with the plasmid pGB7 suggests that essential information for the heterologous expression of Pep5 production is missing on this plasmid (Bierbaum et al., 1994). Just as in the case of epidermin, where the location of one gene (epiK) 
is unknown (Peschel et al., 1993), the information for both of the corresponding Pep5 genes may be located on the chromosome or on one of the other four plasmids of the producer strain (ErsfeldDressen et al., 1984).

The location of potential promoters and transcriptional terminators as indicated in Fig. 2 suggests that the structural gene pepA together with the genes for the essential modification and processing enzymes pepPBC are coordinately transcribed. The promoter in front of pepA is functional as indicated by the clone pMR7 which only contains the structural gene and which produces and accumulates pre-Pep5 (Fig. 5B). Downstream of $p e p A$ there are no further potential promoters for $p e p P, p e p B$ and pep $C$ detectable. The relatively weak terminator downstream of pepA could allow partial readthrough, thus reducing the production of PepP, PepB and PepC and thereby ensuring a high prepeptide/enzyme ratio, while the terminator behind pepC is probably strong enough for transcription termination. However, using a $p e p A$ probe we could not detect any transcript longer than approximately 300 bases indicating that, if a pepAPBC transcript exists, it is rapidly processed. Similar observations were reported for nisin (Engelke et al., 1992; Kuipers et al., 1993) and epidermin (Schnell et al., 1992). Although it cannot be excluded that the short pepI transcript also derives from processing, it could be transcribed as a monocistronic mRNA. In any case, it seems crucial for the Pep5-producing strain to ensure a balanced production ratio between the lantibiotic and the immunity peptide; it remains to be studied how this is achieved. Previous work has shown that there is no expression of the immunity phenotype when pepA is deleted or truncated (Reis et al., 1994) and it appears not inconceivable that the prepeptide in any stage of modification participates in the activation of the pepI promoter.

Roles of PepP and PepT in Pep5 biosynthesis. The fact that pepIAPBC was sufficient to transform the $\mathrm{pED} 503$-cured variant of $S$. epidermidis 5 into a Pep5 producer demonstrates that PepT is not essential for Pep5 in the homologous host (Bierbaum et al., 1994). However, there are indications that the host-provided translocators apparently substituting for PepT are less efficient and that, for high production rates, PepT is indispensable. The strongest argument for such an interpretation is the observation that, in the absence of PepT, Pep5 yields drop to approximately $10 \%$ (Fig. 5A). The substituting transporters probably act more slowly because of the thioether-based ring structures; the PepCdeficient strain excretes more processed Pep5 and accumulates less unprocessed prepeptide inside the cells than the PepP-deficient clone; a higher production was also observed with a mutated Pep5 molecule from which the bulky ring $\mathrm{C}$ had been deleted by site-directed mutagenesis (Bierbaum et al., unpublished). Our results compare well with the epidermin transporter: epiT' $T^{\prime \prime}$ is a discontinous gene which is not necessary for epidermin production in a heterologous host (Schnell et al., 1992; Augustin et al., 1992).

In contrast, the protease PepP is essential for cleaving off the leader sequence after the propeptide has been modified. Our results show that PepP is the only protease of the producer strain which is able to recognize the specific cleavage site of pre-Pep5; processing by other proteases is possible but yields truncated peptides which show strongly reduced antibacterial activities. The importance of dedicated proteases is also reflected by the fact that, with the exception of subtilin, proteases have been found in all lantibiotic gene clusters sequenced so far. Like PepP, NisP and EpiP belong to the family of the subtilisin-like serine proteases (Siezen et al., 1991; Van der Meer et al., 1993) and both show the features of pre-pro-proteins with a characteristic $\mathrm{N}$-terminal procaryotic secretory signal sequence and a potential signal peptidase cleavage site (Siezen et al., 1991; Van der Meer et al., 1993). In addition, the last 30 amino acids of the C-terminus of NisP show a sequence similarity to a consensus membrane anchor sequence which suggests an export across the cell envelope and the attachment to the cellular membrane. PepP does not have a signal sequence and must be located in the cytoplasm because no prepeptide was detected outside the cell after inactivation of PepP, in contrast to the results that were obtained with a clone of Lactococcus lactis harbouring nisABTCIR without a functional nisP (Van der Meer et al., 1993). This also substantiates the interpretation that Pep5 must be processed inside the cell. The putative ElkP protease, that is encoded in the epilancin $\mathrm{K} 7$ gene cluster of $S$. epidermidis $\mathrm{K} 7$ directly downstream of the elkA structural gene (Van de Kamp et al., 1995), resembles PepP by lacking these sequence attributes and is probably also intracellularly located. Epilancin K7 is structurally more closely related to Pep5 than other lantibiotics which obviously is also reflected in increased organizational and functional similarities of the biosynthetic apparatus.

PepC is a thioether-forming enzyme. The absence of any sequence similarity to known proteins connected LanB and LanC proteins with the modification reactions as soon as the respective genes were first described (Schnell et al., 1991). In spite of this, there is no experimental evidence so far as to the exact function of these enzymes. It was assumed that one enzyme would be involved in dehydration of hydroxyamino acids while the other would catalyze the ring formation. However, spontaneous addition of thiol groups at ambient temperature is possible and has been used in the structure determination of lantibiotics and, therefore, was discussed as an alternative (Jung, 1991). Also, it was not clear whether dehydration and ring formation would indeed be separate processes or catalyzed in one step. The construction of a PepC-deficient clone and the characterization of its secretion products now allows us to unambigously asign a function to this protein as well as to deduce the function of the PepB protein.

The PepC-deficient clone secretes completely dehydrated Pep5 peptides, thus excluding the possibility that PepC is itself involved in dehydration. Instead, the majority of the peptides do not contain thioether amino acids, none of the peptides possesses the correct thioether pattern and just a small fraction, an estimated $20 \%$ of the total peptides purified, contains one lanthionine molecule out of three. This strongly suggests that PepC is responsible for thioether formation; it seems reasonable to assume that PepC binds to the dehydrated prepeptide and stabilizes a prepeptide conformation which enables the sulfhydryl groups to add to the correct dehydroamino acid. Apparently, in the absence of PepC and consequently of thioether rings, and possibly also in the absence of the correct exporter PepT, which could create a transport bottle neck and prolong the time during which the peptides are exposed to intracellular proteases, unbridged Pep5 peptides are subject to proteolytic destruction; particularly, the Gly29-Lys 30 bond is susceptible to hydrolysis, also indicating that in the peptide which contains one lanthionine Cys33 may be part of the ring bridging to one of the N-terminally located dehydroamino acids. The partial formation of this ring could be facilitated by transient stabilization of a peptide structure during some biosynthetic reaction such as processing or transmembrane translocation.

Model for the biosynthesis of Pep5-type lantibiotics. The identification of PepC as the thioether-forming protein makes it very likely that the dehydration of Ser and Thr residues is catalyzed by PepB. This interpretation is supported by the previous isolation of completely unmodified prepeptide from clone $S$. 
epidermidis 5- pMR7 (Sahl et al., 1991) which contains only the structural gene but none of the biosynthetic genes (Table 1). This strain accumulates the prepeptide inside the cells and does not secrete any processed peptide (Fig. 5). Similarly, in clone pMR4 which contains pepIAP but lacks pepB and pepC, only accumulation but no processing and secretion are detectable (Fig. 5). As there is no reason to assume that the immunity peptide or the protease are involved in dehydration, this function can only be attributed to PepB. Another interesting observation is that, although the protease is present in clone pMR4, obviously processing does not take place; this indicates that PepP may not recognize the cleavage site unless $\mathrm{Thr}^{+1}$ is dehydrated to Dhb. It is also remarkable that, at least with the expression system used in this study where PepT is missing, Pep5 cannot be transported in the unprocessed form. Secretion of modified but uncleaved nisin in NisP-deficient clones was recently reported by Van der Meer et al. (1993), in which case however the processing protease is located outside the cell.

Based on the present and previously published results (Weil et al., 1990; Sahl et al., 1991), it is possible to draw a rather precise picture of the sequence of events and cellular locations of the reactions leading to mature Pep5.

a) The prepeptide is ribosomally synthesized and rapidly dehydrated in its propeptide part by PepB.

b) The dehydrated prepeptide binds to PepC which folds Pep5 in such a way that correct thioether formation is possible.

c) The completely modified prepeptide is processed by PepP inside the cells.

d) Mature Pep5 is exported from the cells by PepT which can be functionally substituted to some extent by other hostencoded transporters. A somewhat relaxed substrate specificity of ABC transporters is well documented (Fath and Kolter, 1993).

e) PepI protects the producing cells by an as-yet-unknown mechanism (Reis et al., 1994). However, it is interesting to mention that PepI has no equivalent in any other lantibiotic gene cluster and that processing proteases are supposed to be extracellular proteins (Sahl et al., 1995) except in the case of Pep5, lactocin S (Skaugen, 1994) and epilancin K7 (Van de Kamp et al., 1995); it may well be that the intracellular processing of Pep5 requires a particular protection mechanism.

Currently, experiments are in progress to isolate the Pep5 biosynthetic enzymes, in particular PepB and PepC, and to verify their functions in vitro.

This work was supported by the Deutsche Forschungsgemeinschaft (Sa 292/6-1, 6-2). Parts were also funded by the European Communities (BIOT-CT91-0265). The authors are indebted to M. Josten and C. Szekat for excellent technical assistance, V. Gnau for peptide sequencing and G. Klemm for photographic work. G. Jung and F. Götz and their research groups are thanked for cooperative and open discussions and exchange of material. R. Siezen is acknowledged for drawing our attention to the serine protease nature of PepP.

\section{REFERENCES}

Ambulos, P. N. Jr, Duvall, E. J. \& Lovett, P. S. (1987) Gene 51, $281-$ 286.

Augustin, J. \& Götz, F. (1990) FEMS Microbiol. Lett. 66, 203-208.

Augustin, J., Rosenstein, R., Wieland, B., Schneider, U., Schnell, N., Engelke, G., Entian, K.-D. \& Götz, F. (1992) Eur. J. Biochem. 204, 1149-1154.

Banerjee, S. \& Hansen, J. N. (1988) J. Biol. Chem. 263, 9508-9514.

Bierbaum, G., Reis, M., Szekat, C. \& Sahl, H.-G. (1994) Appl. Env. Microbiol. 60, 4332-4338.

Birnboim, H. C. \& Doly, J. (1979) Nucleic Acids Res. 7, 1513-1523.

Bolivar, F., Rodriguez, R. L., Greene, P. J., Betlach, M. C., Heyneker, H. L. \& Boyer. H. W. (1977) Gene 2, 95-113.
Chassy, B. M. \& Murphy, C. M. (1993) in Bacillus subtilis and other gram-positive bacteria (Sonenshein, A. L., Hoch, J. A. \& Losick, R., eds) pp. 65-82, American Society for Microbiology, Washington DC.

Chung, Y. J. \& Hansen, J. N. (1992) J. Bacteriol. 174, 6699-6702.

Chung, Y. J., Steen, M. T. \& Hansen, J. N. (1992) J. Bacteriol. 174, $1417-1422$.

Dente, L., Cesareni, G. \& Cortese, R. (1983) Nucleic Acids Res. II, $1645-1655$.

Dodd, H. M., Horn, N. \& Gasson, M. J. (1990) J. Gen. Microbiol, 136, 555-566.

Dotto, G. P., Enea, V. \& Zinder, N. D. (1981) Virology 114, 463-473.

Engelke, G., Gutowski-Eckel, Z., Hammelmann, M. \& Entian, K.-D. (1992) Appl. Env. Microbiol. 58, 3730-3743.

Engelke, G., Gutowski-Eckel, Z., Kiesau, P., Siegers, K., Hammelmann, M. \& Entian, K.-D. (1994) Appl. Env. Microbiol. 60, 814-825.

Ersfeld-Dressen, H., Sahl, H.-G. \& Brandis, H. (1984) J. Gen. Microbiol. $130,3029-3035$.

Fath, M. J. \& Kolter, R. (1993) Microbiol. Rev. 57, 995-1017.

Gutowski-Eckel, Z., Klein, C., Siegers, K., Bohm, K., Hammelmann, M. \& Entian, K.-D. (1994) Appl. Env. Microbiol. 60, 1-11.

Higgins, D. G., Bleasby, A. J. \& Fuchs, R. (1992) Comput. Appl. Biol. Sci. 8, 189-191.

Holmes, D. S. \& Quigley, M. (1981) Anal. Biochem. 114, 193-197.

Jung, G. (1991) in Nisin and novel lantibiotics (Jung, G. \& Sahl, H.-G., eds) pp. 1-34, ESCOM, Leiden.

Kaletta, C., Entian, K.-D., Kellner, R., Jung, G., Reis, M. \& Sahl, H.-G. (1989) Arch. Microbiol. 152, 16-19.

Klein, C., Kaletta, C., Schnell, N. \& Entian, K.-D. (1992) Appl. Env. Microbiol. 58, 132-142.

Klein, C., Kaletta, C. \& Entian, K.-D. (1993) Appl. Env. Microbiol. 59, $296-303$.

Klein, C. \& Entian, K.-D. (1994) Appl. Env Microbiol. 60, 2793-2801.

Kuipers, O. P., Beerthuyzen, M. M., Siezen, R. J. \& de Vos, W. M. (1993) Eur. J. Biochem. 216, 281-292.

Kupke, T., Kempter, C., Gnau, V., Jung, G. \& Götz, F. (1994) J. Biol. Chem. 269, 5653-5659.

Maxam, A. M. \& Gilbert, W. (1980) Methods Enzymol. 65, 499-560.

McMaster, G. K. \& Carmichael, G. G. (1977) Proc. Natl Acad. Sci. USA $74,4835-4840$.

Oskouian, B. \& Stewart, G. C. (1990) J. Bacteriol. 172, 3804-3812.

Peschel, A., Augustin, J., Kupke, T., Stevanovic, S. \& Götz, F. (1993) Mol. Microbiol. 9, 31-39.

Poolman, B., Royer, T. J., Mainzer, S. E. \& Schmidt, B. S. (1990) J. Bacteriol. $172,4037-4047$.

Reis, M. \& Sahl, H.-G. (1991) in Nisin and novel lantibiotics (Jung, G. \& Sahl, H.-G., eds) pp. 320-331, ESCOM, Leiden.

Reis, M., Eschbach-Bludau, M., Iglesias-Wind, M. I., Kupke, T. \& Sahl, H.-G. (1994) Appl. Env. Microbiol. 60, 2876-2883.

Rince, A., Dufour, A., Le Pogam, S., Thuault, D., Bourgeois, C. M. \& Le Pennec, J. P. (1994) Appl. Env. Microbiol. 60, 1652-1657

Sahl, H.-G. \& Brandis, H. (1981) J. Gen. Microbiol. 127, 377-384.

Sahl, H.-G., Grossgarten, M., Widger, W. R., Cramer, W. A. \& Brandis, H. (1985) Antimicrob. Agents Chemother. 27, 836-840.

Sahl, H.-G., Reis, M., Eschbach, M., Szekat, C., Beck-Sickinger, A. G. Metzger, J., Stevanovic, S. \& Jung, G. (1991) in Nisin and novel lantibiotics (Jung, G. \& Sahl, H.-G., eds) pp. 347-358, ESCOM, Leiden.

Sahl, H.-G., Jack, R. W. \& Bierbaum, G. (1995) Eur. J. Biochem 230, $827-853$.

Saiki, R. K., Gelfand, D. H., Stoffel, S., Scharf, S. J., Higuchi, R., Horn, G. T., Mullis, K. B. \& Ehrlich, H. A. (1988) Science 239, 487-491.

Sambrook, J., Fritsch, E. F. \& Maniatis, T. (1989) Molecular cloning: a laboratory manual, 2nd edn, Cold Spring Harbor Laboratory Press, Cold Spring Harbor NY.

Sanger, F., Nicklen, S. \& Coulson, A. R. (1977) Proc. Natl Acad. Sci. USA 74, 5463-5467.

Schleifer, K. H. \& Fischer, U. (1982) Int. J. Syst. Bacteriol. 32, 153156.

Schnell, N., Entian, K.-D., Schneider, U., Götz, F., Zähner, H., Kellner, R. \& Jung, G. (1988) Nature 333, 276-278.

Schnell, N., Engelke, G., Augustin, J., Rosenstein, R., Götz, F. \& Entian, K.-D. (1991) in Nisin and novel lantibiotics (Jung, G. \& Sahl, H.G., eds), pp. 269-276, ESCOM, Leiden. 
Schnell, N., Engelke, G., Augustin, J., Rosenstein, R., Ungermann, V., Götz, F. \& Entian, K.-D. (1992) Eur. J. Biochem. 204, 57-68.

Siezen, R. J., de Vos, W. M., Leunissen, J. A. M. \& Dijkstra, B. W. (1991) Protein Eng. 7, 719-737.

Skaugen, M. (1994) PhD thesis, Agricultural University of Norway, As.

Skaugen, M., Nissen-Meyer, J., Jung, G., Stevanovic, S., Sletten, K., Mortvedt-Abildgaard, C. I. \& Nes, I. F. (1994) J. Biol. Chem. 269, $27183-27185$.

Thompson, J. D., Higgins, D. G. \& Gibson, T. J. (1994) Nucleic Acids Res. 22, 4673-4680.

Van de Kamp, M., van den Hooven, H. W., Konings, R. N. H., Hilbers, C. W., van de Ven, F. J. M., Bierbaum, G., Sahl, H.-G., Kuipers, O.
P., Siezen, R. J. \& de Vos, W. M. (1995) Eur. J. Biochem. 230, 587600.

Van der Meer, J. R., Polman, J., Beerthuyzen, M. M., Siezen, R. J., Kuipers, O. P. \& de Vos, W. M. (1993) J. Bacteriol. I75, 25782588.

Vieira, J. \& Messing, J. (1982) Gene 19, 259-268.

Weil, H.-P., Beck-Sickinger, A. G., Metzger, J., Stevanovic, S., Jung, G., Josten, M. \& Sahl, H.-G. (1990) Eur. J. Biochem. 194, 217223.

Yanisch-Perron, C., Vieira, J. \& Messing, J. (1985) Gene 33, $103-$ 109.

Zell, R. \& Fritz, H. (1987) EMBO J. 6, 1809-1815. 